Federal Reserve Bank of Dallas

Globalization and Monetary Policy Institute

Working Paper No. 126

http://www.dallasfed.org/assets/documents/institute/wpapers/2012/0126.pdf

\title{
Ultra Easy Monetary Policy and the Law of Unintended Consequences*
}

\author{
William R. White
}

August 2012

Revised: September 2012

\begin{abstract}
In this paper, an attempt is made to evaluate the desirability of ultra easy monetary policy by weighing up the balance of the desirable short run effects and the undesirable longer run effects - the unintended consequences. The conclusion is that there are limits to what central banks can do. One reason for believing this is that monetary stimulus, operating through traditional ("flow") channels, might now be less effective in stimulating aggregate demand than previously. Further, cumulative ("stock") effects provide negative feedback mechanisms that over time also weaken both supply and demand. It is also the case that ultra easy monetary policies can eventually threaten the health of financial institutions and the functioning of financial markets, threaten the "independence" of central banks, and can encourage imprudent behavior on the part of governments. None of these unintended consequences is desirable. Since monetary policy is not "a free lunch", governments must therefore use much more vigorously the policy levers they still control to support strong, sustainable and balanced growth at the global level.
\end{abstract}

JEL codes: E52, E58

\footnotetext{
* William R. White is currently the chairman of the Economic Development and Review Committee at the OECD in Paris. He was previously Economic Advisor and Head of the Monetary and Economic Department at the Bank for International Settlements in Basel, Switzerland. +41 (0) 798349066. white.william@sunrise.ch. This is a slightly revised version of the paper circulated in August 2012. The views in this paper are those of the author and do not necessarily reflect the views of organizations with which the author has been or still is associated, the Federal Reserve Bank of Dallas or the Federal Reserve System.
} 


\section{Ultra Easy Monetary Policy and the Law of Unintended Consequences ${ }^{2}$}

\section{By William White}

\begin{abstract}
"This long run is a misleading guide to current affairs. In the long run we are all dead. Economists set themselves too easy, too useless a task if in tempestuous seasons they can only tell us that when the storm is long past the sea is flat again".
\end{abstract}

John Maynard Keynes

\begin{abstract}
"No very deep knowledge of economics is usually needed for grasping the immediate effects of a measure; but the task of economics is to foretell the remoter effects, and so to allow us to avoid such acts as attempt to remedy a present ill by sowing the seeds of a much greater ill for the future".

Ludwig von Mises
\end{abstract}

\section{A. Introduction}

The central banks of the advanced market economies (AME's) ${ }^{3}$ have embarked upon one of the greatest economic experiments of all time - ultra easy monetary policy. In the aftermath of the economic and financial crisis which began in the summer of 2007, they lowered policy rates effectively to the zero lower bound (ZLB). In addition, they took various actions which not only caused their balance sheets to swell enormously, but also increased the riskiness of the assets they chose to purchase. Their actions also had the effect of putting downward pressure on their exchange rates against the currencies of Emerging Market Economies (EME's). Since virtually all EME's tended to resist this pressure ${ }^{4}$, their foreign exchange reserves rose to record levels, helping to lower long term rates in AME's as well. Moreover, domestic monetary conditions in the EMEs were eased as well. The size and global scope of these discretionary policies makes them historically unprecedented. Even during the Great Depression of the 1930's, policy rates and longer term rates in the most affected countries (like the US) were never reduced to such low levels ${ }^{5}$.

In the immediate aftermath of the bankruptcy of Lehman Brothers in September 2008, the exceptional measures introduced by the central banks of major AME's were rightly and

\footnotetext{
${ }^{2}$ The views expressed here are personal. They do not necessarily represent the views of organizations with which the author has been or still is associated.

${ }^{3}$ It is important to note that, in spite of many similarities in the policies of various AME central banks, there have also been important differences. See White (2011),

${ }^{4}$ This phenomenon was not in fact confined to EME's. A number of smaller AME's, like Switzerland, have also resisted upward pressure on their exchange rates.

${ }^{5}$ See Bank for International Settlements (2012) Graph 1V.8
} 
successfully directed to restoring financial stability. Interbank markets in particular had dried up, and there were serious concerns about a financial implosion that could have had important implications for the real economy. Subsequently, however, as the financial system seemed to stabilize, the justification for central bank easing became more firmly rooted in the belief that such policies were required to restore aggregate demand ${ }^{6}$ after the sharp economic downturn of 2009. In part, this was a response to the prevailing orthodoxy that monetary policy in the 1930's had not been easy enough and that this error had contributed materially to the severity of the Great Depression in the United States. ${ }^{7}$ However, it was also due to the growing reluctance to use more fiscal stimulus to support demand, given growing market concerns about the extent to which sovereign debt had built up during the economic downturn. The fact that monetary policy was increasingly seen as the "only game in town" implied that central banks in some AME's intensified their easing even as the economic recovery seemed to strengthen through 2010 and early 2011. Subsequent fears about a further economic downturn, reopening the issue of potential financial instability ${ }^{8}$, gave further impetus to "ultra easy monetary policy".

From a Keynesian perspective, based essentially on a one period model of the determinants of aggregate demand, it seemed clearly appropriate to try to support the level of spending. After the recession of 2009, the economies of the AME's seemed to be operating well below potential, and inflationary pressures remained subdued. Indeed, various authors used plausible versions of the Taylor rule to assert that the real policy rate required to reestablish a full employment equilibrium (and prevent deflation) was significantly negative. Such findings were used to justify the use of non standard monetary measures when nominal policy rates hit the ZLB.

There is, however, an alternative perspective that focuses on how such policies can also lead to unintended consequences over longer time periods. This strand of thought also goes back to the pre War period, when many business cycle theorists ${ }^{9}$ focused on the cumulative effects of bank-created-credit on the supply side of the economy. In particular, the Austrian school of thought, spearheaded by von Mises and Hayek, warned that credit driven expansions would

\footnotetext{
${ }^{6}$ See in particular Bernanke (2010). The reasons for conducting QE2 seem to differ substantially from the reasons for conducting QE1.

${ }^{7}$ Bernanke (2002)

${ }^{8}$ The catalyst for these fears was a sharp slowdown in Europe. This was driven by concerns about sovereign debt in a number of countries in the euro zone, and associated concerns about the solvency of banks that had become over exposed to both private and sovereign borrowers. Also of importance were fears of the "fiscal cliff" in the US. This involved existing legislation which, unless revised, would cut the US deficit by about 4 percent of GDP beginning in January 2013. As discussed below, this prospect had a chilling effect on corporate investment and hiring well before that date.

${ }^{9}$ For an overview, see Haberler (1939). Laidler (1999) has a particularly enlightening chapter on Austrian theory, and the main differences between the Austrians and Keynesians. He then notes (p.49) "It would be difficult, in the whole history of economic thought, to find coexisting two bodies of doctrine which so grossly contradict one another."
} 
eventually lead to a costly misallocation of real resources ("malinvestments") that would end in crisis. Based on his experience during the Japanese crisis of the 1990's, Koo (2003) pointed out that an overhang of corporate investment and corporate debt could also lead to the same result (a "balance sheet recession").

Researchers at the Bank for International Settlements have suggested that a much broader spectrum of credit driven "imbalances" ${ }^{10}$ ", financial as well as real, could potentially lead to boom-bust processes that might threaten both price stability and financial stability ${ }^{11}$. This BIS way of thinking about economic and financial crises, treating them as systemic breakdowns that could be triggered anywhere in an overstretched system, also has much in common with insights provided by interdisciplinary work on complex adaptive systems. This work indicates that such systems, built up as a result of cumulative processes, can have highly unpredictable dynamics and can demonstrate significant non linearities ${ }^{12}$. The insights of George Soros, reflecting decades of active market participation, are of a similar nature. ${ }^{13}$

As a testimony to this complexity, it has been suggested that the threat to price stability could also manifest itself in various ways. Leijonhufvud (2012) contends that the end results of such credit driven processes could be either hyperinflation or deflation ${ }^{14}$, with the outcome being essentially indeterminate prior to its realization. Indeed, Reinhart and Rogoff (2009) and Bernholz (2006) indicate that there are ample historical precedents for both possible outcomes. ${ }^{15}$ As to the likelihood that credit driven processes will eventually lead to financial instability, Reinhart and Rogoff (2009) note that this is a common outcome, though they also

\footnotetext{
${ }^{10}$ An "imbalance" is defined roughly as a "sustained and substantial deviation from historical norms", for which there is no compelling analytical explanation.

${ }^{11}$ See in particular the many works authored or coauthored by Claudio Borio, including Borio and White (2003). See also White (2006). The origins of this way of thinking go back to the work of Alexander Lamfalussy and possibly even before. See Clement (2010) on the origins of the word "macroprudential", whose first recorded use at the BIS was in 1979.

${ }^{12}$ There is a long history (although never mainstream) of treating the economy as a complex, adaptive system. It goes back to Veblen and even before. However, this approach received significant impetus with the founding of the Santa Fe Institute in the early 1990's. See Waldrop (1992). For some recent applications of this type of thinking see Beinhocker (2006) and Haldane (2012). From this perspective, an economy shares certain dynamic characteristics with other complex systems. Buchanan (2002) suggests the following. First, crises occur on a regular basis in complex systems. They also conform to a Power Law linking the frequency of crises to the inverse of their magnitude. Second, predicting the timing of individual crises is impossible. Third, there is no relationship between the size of the triggering event and the magnitude of the subsequent crisis. This way of thinking helps explain why "the Great Moderation" could have been followed by such great turbulence, and why major economic crises have generally emerged suddenly and with no clear warning.

${ }^{13}$ Soros has written prolifically on these themes over many years. For a recent summary of his views, see Soros (2010)

${ }^{14}$ In earlier publications, Leijonhufvud referred to the "corridor of stability" in macroeconomies. Outside this corridor, he suggests that forces prevail which encourage an ever widening divergence from equilibrium. See also White (2008)

${ }^{15}$ This helps explain the coexistence today of two schools of thought among investors about future price developments.
} 
note that the process more commonly begins with a recession feeding back on the financial system than the other way around ${ }^{16}$. Reinhart and Reinhart (2010) document the severity and durability of downturns characterized by financial crisis, implying that this complication would seem more likely to shift the balance of macroeconomic outcomes towards deflation rather than inflation.

In this paper, an attempt is made to evaluate the desirability of ultra easy monetary policy by weighing up the balance of the desirable short run effects and the undesirable longer run effects - the unintended consequences. In Section B, it is suggested that there are grounds to believe that monetary stimulus operating through traditional ("flow") channels might now be less effective in stimulating aggregate demand than is commonly asserted. In Section C, it is further contended that cumulative ("stock") effects provide negative feedback mechanisms that also weaken growth over time. Assets purchased with created credit, both real and financial assets, eventually yield returns that are inadequate to service the debts associated with their purchase. In the face of such "stock" effects, stimulative policies that have worked in the past eventually lose their effectiveness.

It is also argued in Section C that, over time, easy monetary policies threaten the health of financial institutions and the functioning of financial markets, which are increasingly intertwined. This provides another negative feedback loop to threaten growth. Further, such policies threaten the "independence" of central banks, and can encourage imprudent behavior on the part of governments. In effect, easy monetary policies can lead to moral hazard on a grand scale ${ }^{17}$. Further, once on such a path, "exit" becomes extremely difficult. Finally, easy monetary policy also has distributional effects, favoring debtors over creditors and the senior management of banks in particular. None of these "unintended consequences" could be remotely described as desirable.

The force of these arguments might seem to lead to the conclusion that continuing with ultra easy monetary policy is a thoroughly bad idea. However, an effective counter argument is that such policies avert near term economic disaster and, in effect, "buy time" to pursue other policies that could have more desirable outcomes. Among these policies might be suggested ${ }^{18}$ more international policy coordination and higher fixed investment (both public and private) in AME's. These policies would contribute to stronger aggregate demand at the global level. This would please Keynes. As well, explicit debt reduction, accompanied by structural reforms to redress other "imbalances" and increase potential growth, would make remaining debts more easily serviceable. This would please Hayek. Indeed, it could be suggested that a combination of

\footnotetext{
${ }^{16}$ See Reinhart and Rogoff (2009)p.145. "Severe financial crises rarely occur in isolation. Rather than being the trigger of recession, they are more often an amplification mechanism".

${ }^{17}$ This is discussed further in White (2004)

${ }^{18}$ White (2012b)
} 
all these policies must be vigorously pursued if we are to have any hope of achieving the "strong, sustained and balanced growth" desired by the G 20. We do not live in an "either-or" world.

The danger remains, of course, that ultra easy monetary policy will be wrongly judged as being sufficient to achieve these ends. In that case, the "bought time" would in fact have been wasted $^{19}$. In this case, the arguments presented in this paper then logically imply that monetary policy should be tightened, regardless of the current state of the economy, because the near term expected benefits of ultra easy monetary policies are outweighed by the longer term expected costs. Undoubtedly this would be very painful, but (by definition) less painful than the alternative of not doing so. John Kenneth Galbraith touched upon a similar practical conundrum some years ago when he said ${ }^{20}$

"Politics is not the art of the possible.

It is choosing between the unpalatable and the disastrous".

This might well be where the central banks of the AME's are now headed, absent the vigorous pursuit by governments of the alternative policies suggested above.

\section{B. Will Ultra Easy Monetary Policy Stimulate the Real Economy?}

Stimulative monetary policies are commonly referred to as "Keynesian". However, it is important to note that Keynes himself was not convinced of the effectiveness of easy money in restoring real growth in the face of a Deep Slump. This is one of the principal insights of the General Theory. ${ }^{21}$ In current circumstances, two questions must be addressed. First, will ultra easy monetary conditions be effectively transmitted to the real economy? Second, assuming the answer to the first question is yes, will private sector spending respond in such a way as to stimulate the real economy and reduce unemployment? It is suggested in this paper that the answer to both questions is no.

\section{a) Ultra Easy Monetary Policy and the Transmission Mechanism}

When the crisis first started in the summer of 2007 the response of AME central banks was quite diverse. Some, like the ECB, remained focused on resisting inflation which was rising under the influence of higher prices for food and energy. Others, like the Federal Reserve, lowered policy rates swiftly and by unprecedented amounts. However, by the end of 2008,

\footnotetext{
${ }^{19}$ Governor Shirakawa of the Bank of Japan has made this argument particularly forcefully. See Shirakawa (2012a and 2012b). It also resonates strongly in both Europe and the United States. Their respective central bank heads have repeatedly called on governments to take the necessary measures to deal with fiscal and other problems that are ultimately government responsibilities. See also Issing (2012) p3 and Fisher (2012). Both have stressed repeatedly that that there are clear limits to what central banks can do.

${ }^{20}$ Galbraith (1993).

${ }^{21}$ See Keynes (1936). As noted below, however, this skepticism seemed to mark a change from his earlier thinking.
} 
against the backdrop of the failure of Lehman Brothers and declining inflation, virtually all AME central banks were in easing mode and policy rates were reduced virtually to zero. This response showed clearly the capacity of central banks to act. At the same time, having lowered policy rates to or near the ZLB, these actions also implied a serious limitation on the further use of traditional monetary policy instruments. Further, as time wore on, doubts began to emerge about the effectiveness of some of the traditional channels of transmission of monetary policy.

An important source of concern was whether lower policy rates would be effectively transmitted along the yield curve to longer maturities. Due to the potentially interacting effects of rising term and credit spreads, long rates might fall less than normally (or indeed might even rise) in response to lower policy rates. This phenomenon has already been witnessed in a number of peripheral countries in the eurozone area. After years of declining long rates driven by "convergence trades", prospects of continuing slow growth (or even recession) in these countries raised concerns about the continued capacity of their governments to service rising debt levels. The European Central Bank took various steps to support the prices of sovereign bonds in the various countries affected, but these measures have not thus far proved successful. $^{22}$

In contrast, for sovereigns deemed not to have counterparty risk, there has been no evidence of such problems. Indeed, long term sovereign rates in the US, Germany, Japan and the UK followed policy rates down and are now at unprecedented low levels. However, there can be no guarantee that this state of affairs will continue. One disquieting fact is that these long rates have been trending down, in both nominal and real terms, for almost a decade and there is no agreement as to why this has occurred. ${ }^{23}$ Many commentators have thus raised the possibility of a bond market bubble that will inevitably burst ${ }^{24}$. Further, long term sovereign rates in favored countries could yet rise due to growing counterparty fears. In all the large countries noted above, the required swing in the primary balance needed just to stabilize debt to GNE ratios (at high levels), is very large ${ }^{25}$. Such massive reductions in government deficits could be

\footnotetext{
${ }^{22}$ The ECB directly purchased such bonds in 2010 and 2011 under its SMP program. More recently it has extended LTRO facilities, with some of the funds provided being used by banks to purchase bonds issued by their national sovereigns. Critics of these policies contend that the ECB could lower these bond spreads if it were to announce a target for such spreads and make credible its will to impose it. For various reasons, both economic and political, the ECB has thus far chosen not to do this. However, it remains an open issue.

${ }^{23}$ For a fuller analysis of the potential contributing factors, see Turner (2011)

${ }^{24}$ Perhaps the best known market participant to express this view was Bill Gross of Pimco, though he has subsequently changed his mind.

${ }^{25}$ For calculations indicating how large the needed swing might be, see Cecchetti et al (2010). Their calculations indicate the primary surplus must swing by 15 percentage points of GDP in the United Kingdom and Japan, and 11 percentage points in the United States. Generally speaking, the adjustments required in large continental European economies are smaller.
} 
hard to achieve in practice. In the US and Japan, in particular, the absence of political will to confront evident problems has already led to downgrades by rating agencies ${ }^{26}$.

As for private sector counterparty spreads, mortgage rates in a number of countries have not followed policy rates down to the normal extent. In the United States in particular, as the Fed Funds rate fell sharply from 2008 onwards, the 30 year FNMA rate declined much less markedly ${ }^{27}$. In part, widening mortgage spreads reflect increased concentration in the mortgage granting business since the crisis began, and also increased costs due to regulation. However, it also reflects the global loss of trust in financial institutions, which has led to higher wholesale funding costs. In addition, costs of funds have risen in many countries due to the failure of deposit rates to fully reflect declines in policy rates ${ }^{28}$. A fuller discussion of the effects of low interest rates on the financial industry is reserved for later

Spreads for corporate issues have also fallen less than might normally have been expected, even if the absolute decline has been very substantial. Nevertheless, these spreads could rise again if the economy were to weaken or even if economic uncertainties were to continue. Paradoxically, a rise in corporate spreads might even be more likely should governments pursue credible plans for fiscal tightening ${ }^{29}$. These plans might well involve tax increases and spending cuts that could have material implications for both forward earnings and companies net worth. This could conceivably increase risk premia on corporate bonds.

A further concern is that the reductions in real rates seen to date, associated with lower nominal borrowing rates and seemingly stable inflationary expectations, might at some point be offset by falling inflationary expectations. In the limit, expectations of deflation could not be ruled out. This in fact was an important part of the debt/ deflation process first described by Irving Fisher in 1936. The conventional counterargument is that such tendencies can be offset by articulation of explicit inflation targets to stabilize inflationary expectations. Even more powerful, a central bank could commit to a price level target, implying that any price declines would have subsequently to be offset by price increases ${ }^{30}$.

However, there are at least two difficulties with such targeting proposals. The first is making the target credible when the monetary authorities' room for maneuver has already been

\footnotetext{
${ }^{26}$ The recent ratings downgrade of the US was not due to any change in the objective economic circumstances. Rather, it reflected an assessment that a dysfunctional Congress was increasingly unlikely to make the compromises necessary to achieve a meaningful reduction of the US deficit.

${ }^{27}$ Moreover, average effective rate on outstanding US mortgages fell even less; homeowners with negative effective equity were unable to refinance their mortgages at lower rates, as in earlier cycles.

${ }^{28}$ On this general question of the increased cost of financial intermediation see Lowe (2012).

${ }^{29}$ See Dugger (2011). Dugger introduces the concept of Fiscal Adjustment Cost (FAC) discounting. He contends that companies are already assessing the effects of fiscal constraint on their own balance sheets and earnings. In effect "they begin to treat long term fiscal shortfalls as present value off balance sheet (corporate) liabilities".

${ }^{30}$ This is very similar to the process that worked under the gold standard. Falling prices were expected to reverse, thus lowering the ex ante real interest rate and encouraging prices to rise.
} 
constrained ${ }^{31}$ by the zero lower bound problem (ZLB). The second objection is even more fundamental; namely, the possibility that inflationary expectations are not based primarily on central banker's statements of good intent. Historical performance concerning inflation, changing perceptions about the central banks capacity and willingness to act, and other considerations could all play a role. The empirical evidence on this issue is not compelling in either direction ${ }^{32}$.

Lower interest rates are not the only channel through which monetary conditions in AME's might be eased further. Whether via lower interest rates or some other central bank actions, reflationary forces could be imparted to the real economy through nominal exchange rate depreciation ${ }^{33}$ and the resulting increase in competitiveness ${ }^{34}$. However, an important problem with this proposed solution is that it works best for a single country. In contrast, virtually all the AME's are near the ZLB and desirous of finding other channels to stimulate the real economy. Evidently, this still leaves the possibility of a broader nominal depreciation of the currencies of AME's vis a vis the currencies of EME's. Indeed, given the trade surpluses of many EME's (not least oil producers), and also the influence of the Balassa-Samuelson effect, a real appreciation of their currencies might be thought inevitable.

The problem rests with the unwillingness of many EME's to accept nominal exchange rate appreciation; the so called "fear of floating". To this end, they have engaged over many years in large scale foreign exchange intervention and easier domestic monetary policies than would otherwise have been the case. More recently, the rhetoric concerning "currency wars" has sharpened considerably, and a number of countries turned for a time to capital controls ${ }^{35}$. The principal concern about these trends in EME's is that they might lead to a more inflationary domestic outcome ${ }^{36}$.

Another channel through which monetary policy is said to work is through higher prices for assets, in particular houses and equities. In effect, higher prices are said to add to wealth and this in turn spurs consumption. Before turning (below) to the latter link in this chain of causation, consider the former one. In those countries in which the crisis raised concern about the health of the banking system (eg; US, UK, Ireland, Greece, Spain) house prices began to

\footnotetext{
${ }^{31}$ For an elegant description of this problem see Yamaguchi (1999). Even today, the Bank of Japan refuses to set a

"target" for inflation, but rather espouses a less ambitious "goal"

${ }^{32}$ See Galati and Melick (2004). Also Galati, Heemiejer and Moessner (2011) which provides a survey of recent theory and the available empirical evidence.

${ }^{33}$ Svenson (2003)

${ }^{34}$ How long nominal depreciation results in a real depreciation is another highly debated issue. Inflation would presumably be less of a problem in countries with high levels of excess capacity. Experience of depreciation in Latin American countries over decades indicates this need not always be the case.

${ }^{35}$ Interestingly, the IMF now seems more willing than hitherto to accept both large scale intervention in foreign exchange markets and capital controls. See Ostry et al (2010)

${ }^{36}$ Recent efforts in China to raise domestic wages in order to spur domestic consumption work in the same direction.
} 
decline sharply early in the crisis. Lower policy rates were not sufficient to reverse this trend. In contrast, in countries where the health of the banking system was never a serious concern, house prices did continue to rise as policy rates were lowered. This has raised concerns of an eventual and aggravated collapse.

As for equity prices, stock indices in the AME's did recovery substantially after policy easing began. However, it is also notable that these increases began to moderate in the summer of 2010 and again in the middle of 2011. In each case, the announcement of some "non standard" policy measure then caused stock prices to rise once again. More broadly, however, the very fact that a number of central banks felt the need to have recourse to such non standard measures indicates that standard measures had failed to produce the stimulative effect desired. The durability of "real" gains supported by the expansion of "nominal" instruments also seems highly questionable.

Finally, an evaluation is needed of the effectiveness of the many "non standard" monetary policy measures that have been taken by central banks in large AMEs, pursuant to reaching the $\mathrm{ZLB}^{37}$. The highly experimental nature of these measures is attested to by various differences observed in what different central banks have actually done. As described by Fahr et al (2011) there are important differences between the practices of the Fed and the ECB.

Perhaps most important, the Fed seems to have treated its "non standard" measures as a substitute for standard monetary policy at the ZLB. In contrast, the ECB treats them as measures to restore market functioning so that the normal channels of the transmission mechanism policy can work properly. Second, while the Fed made increasingly firm pre commitments (though still conditional) to keep the policy rate low for an extended period, the ECB consciously made no such pre commitment Third, whereas the Fed has purchased the liabilities of non financial corporations as well as those of Treasury and Federal agencies, the ECB has lent exclusively to banks and sovereigns. Fourth, while the ECB conducted only repos, in order to facilitate "exit" from non standard measures, the Fed made outright purchases.

Many of the non standard measures taken to date are broadly similar to those undertaken earlier by the Bank of Japan. It is instructive therefore that the Japanese authorities remain highly skeptical of their effectiveness ${ }^{38}$ in stimulating demand. Perhaps the most important reason for this is that the demand for bank reserves tends to rise to match the increase in supply; in short, loan growth does not seem to be much affected. If, in expanding the reserve base, the central bank also absorbs collateral needed to liquefy private markets, that too could be a negative influence. This topic is returned to below.

\footnotetext{
${ }^{37}$ For an early analysis see Borio and Disyatat (2009)

${ }^{38}$ Shirakawa (2012a, 2012b)
} 
It is of course true that still more aggressive unconventional measures could be introduced that might have the effect desired. Indeed, in chastising the Bank of Japan for its timidity, Bernanke (2000) and (2003) explicitly suggested targets for long term interest rates, depreciation of the currency, a higher inflation target (say 3 to 4 percent) and fiscal expansion entirely financed by the central bank. Unfortunately, for each of these policy suggestions there is a convincing counterargument.

Explicit targets for long rates hardly seem required with long rates already at record lows. As for the difficulties of achieving a currency depreciation, these have been discussed above. Recent suggestions for a higher inflation target $^{39}$ have also generated wide spread criticism, particularly since inflation in AME's has stayed stubbornly and unexpectedly high to date. Finally, fiscal expansion entirely funded by monetary creation could, given AME sovereign debt levels generally thought of as "unsustainable", easily raise fears of fiscal dominance and much higher inflation. Perhaps the clearest indication of the force of these counter arguments is that Chairman Bernanke, having proposed these policies almost a decade ago, has not found it appropriate to reassert them more recently, in spite of the ongoing and (again) unexpected weakness of the US recovery ${ }^{40}$.

\section{b) Would private sector demand respond to easier monetary conditions?}

Conventional thinking is that lower interest rates will encourage households to save less (and consume more) and will encourage companies to invest more. In both cases, spending is brought forward from the future, because the discount rate has been reduced. Even abstracting from the influence of cumulative stock considerations (both real and financial) on spending ${ }^{41}$, this conventional thinking can be challenged in a number of ways.

A consideration that applies to both household and company spending is the message given by ultra easy monetary policy. To the extent that such measures are unprecedented, indeed smacking of desperation, they could actually depress confidence and the will to spend. Keynes references to "animal spirits" in the General Theory would seem appropriate here. Indeed, the greater the respect held by the public for the central bank in question, the more likely this outcome might be. Higher respect would increase the likelihood that the public would believe that the central bank had identified problems that they themselves had not foreseen.

\footnotetext{
${ }^{39}$ See Blanchard et al (2011)

${ }^{40}$ Ball (2012) rather attributes to a different cause the unwillingness of Bernanke to pursue his earlier policy prescriptions. Ball suggests that "group think" and a "shy" personality prevented Bernanke from speaking out forcefully at an FOMC briefing in 2003. At this meeting, his earlier suggestions were essentially ruled out by the Fed staff. I think it highly implausible that these character traits would have seriously conditioned Bernanke's behavior over the next nine years, particularly after he became the Chairman of the FOMC.

${ }^{41}$ To be dealt with in the next section of the paper.
} 
A number of other considerations might affect household spending in particular. Perhaps the most important has to do with the assumed positive relationship between the interest rate and the desired rate of saving. While it is conventional wisdom that lower interest rates will stimulate consumption, Bailey (1992) and others have long argued that even the sign of this relationship is ambiguous. Suppose that savers have a predetermined goal for the minimum amount of savings they wish to accumulate over time. This would correspond to someone wishing to purchase an annuity of a certain size upon retirement, at a desired age. Evidently, a lower interest rate always implies a slower rate of accumulation. But, if in fact the accumulation rate becomes so low that it threatens the minimum accumulation goal, the only recourse (other than postponing retirement) will be to save more in the first place ${ }^{42}$. As will be discussed below, a similar logic affects the behavior of those financial institutions (like insurance companies) who have committed to providing annuities or who offer defined benefit pensions.

The distributional (income) implications of interest rate changes for aggregate household spending also receive too little attention. Very low rates imply less household disposable income for creditors and more disposable income for debtors. Should the marginal propensity to consume of creditors (say older, credit constrained people living off accumulated assets) exceed that of debtors, the net effect of redistribution could be to lower household spending rather than raise $\mathrm{it}^{43}$. This argument has in the past been invoked occasionally by central bankers in EME's. More recently, Lardy (2012) and Rogoff (2011) have both recommended ending financial repression in China as a way to raise household consumption. The core of their argument is that higher interest rates would raise disposable income and consumption in turn.

Finally, the argument that higher "wealth" (generated by lower rates causing rising asset prices) will lead to more consumer spending also needs serious reevaluation. While not denying the empirical robustness of this relationship in the past, the argument suffers from a serious analytical flaw. Lower interest rates cannot generate "wealth", if an increase in wealth is appropriately defined as the capacity to have a higher future standard of living ${ }^{44}$. From this perspective, higher equity prices constitute wealth only if based on higher expected productivity and higher future earnings. This could be a byproduct of lower interest rates stimulating spending, but this is simply to assume the hypothesis meant to be under test.

As for higher house prices raising future living standards, the argument ignores the higher future cost of living in a house. Rather, what higher house prices do produce is more collateral against which loans can be taken out to sustain spending. In this case, however, the loan must

\footnotetext{
${ }^{42}$ Strictly speaking this conclusion follows only if the rate of growth of productivity (and economic potential) has also fallen. Thus there must be an increase in saving to reconstitute lost wealth.

${ }^{43}$ As Walter Bagehot put it over a century ago "John Bull can stand many things, but he cannot stand two per cent".

${ }^{44}$ See Bailey (1992) and Merton (2006)
} 
be repaid at the cost of future consumption ${ }^{45}$. No "wealth" has in fact been created. In any event, as noted above, house prices in many countries have continued to fall despite lower policy rates ${ }^{46}$. This implies that the need for "payback" can no longer be avoided by still further borrowing.

A number of counter arguments can also be made to the hypothesis that ultra easy monetary policy will raise corporate investment. First note the fact that investment, as a proportion of GDP, has been trending down in most AME's in recent years. This has occurred in spite of generally solid corporate profits, healthy balance sheets, large cash reserves and very low interest rates over a number of years. A number of reasons have been suggested to explain the lack of investment response to these propitious financial conditions.

The first has been an environment of ever growing uncertainty about a number of important issues; future domestic demand in light of uncertainty about job prospects, future foreign demand given uncertainty about exchange rates and protectionism, and uncertainty as to how the burden of fiscal restraint and possible sovereign debt reduction might affect the corporate sector. A second set of concerns is closely related. In many AME's anti business rhetoric is becoming more common and the political momentum seems to be shifting towards extremism. Moreover, growing concerns about rising income inequality (returned to below) and concerns about the ethical standards of the banking community could all too easily be converted into a broader anti business agenda ${ }^{47}$.

A third reason for continuing low investment seems to have been a secular trend on the part of corporate managements in AME's to maximize cash flow. The incentive for this "short-termism" could be that it allows for larger payouts for both salaries and dividends, also raising equity prices and the value of management options in the bargain. Evidently, however, such behavior comes at the expense of both fixed capital investment and the future health of the firm itself. If low interest rates encourage firms to borrow more money, which they can use for the same short term purposes, then presumably the longer term damage will be even worse.

It has even been suggested that low interest rates have themselves contributed to lower fixed investment in AME's. One channel would be via higher commodity prices (as a result of the public sector investment boom in China), which raises costs in AME's and reduces profits. Perhaps more importantly, many corporations still have significant obligations in the form of defined benefit pension plans. Ramaswamy (2012) presents a chilling quantitative analysis of the effects of interest rate changes on public pension funds and defined benefit funds. The

\footnotetext{
${ }^{45}$ See Muellbauer (2007) and White (2006b)

${ }^{46}$ Some estimates indicate that US householders' equity in their houses fell from a peak of about $\$ 10$ trillion to $\$ 6$ trillion at the end of 2011.

${ }^{47}$ For an analysis of anti business attitudes in the 1930's, under the Roosevelt administration, see Powell (2003) and Smiley (2000).
} 
essence of the argument is that lower interest rates reduce the asset revenues of pension funds and raise the present value of future liabilities. Funding shortfalls eventually have to be made up by the sponsoring company, reducing profits and funds available for investment.

A recent report by the consulting firm Mercer indicates that the 1500 leading companies in the US had a pension deficit of $\$ 689$ billion as of July 2012; i.e., they are only 70 percent funded. In the UK, the Pension Protection Fund recently estimated that almost 85 percent of defined benefit plans were underfunded, with a cumulative shortfall of over $\$ 400$ billion $^{48}$. Moreover, proposed changes to pension rules, in countries using IFRS accounting standards, seem likely to make the impact of low rates on companies with such pension funds significantly worse ${ }^{49}$.

To summarize, there are significant grounds for believing that the various channels through which monetary policy might normally operate are at least partially blocked. Moreover, there are also grounds for belief that neither household nor corporate spending would react as vigorously as in the past, even if the traditional transmission channels were functioning properly. Note too that the issue of "debt stocks", other "imbalances", and the possibility of a "credit crunch" affecting the real economy have not yet even been mentioned. These influences will also weigh on both the capacity to spend and the will to spend, further offsetting the influence of ultra easy monetary policies. As well, such polices can have other unintended consequences which might also tend to grow over time.

\section{Could Ultra Easy Money Have Unintended Consequences?}

The unexpected beginning of the financial and economic crisis ${ }^{50}$, and its unexpected resistance to policy measures taken to date, leads to a simple conclusion. The variety of economic models used by modern academics and by policymakers give few insights as to how the economy really works ${ }^{51}$. If we accept this ignorance as an undesirable reality, then it would also seem hard to deny the possibility that the policy actions taken in recent years might also have unintended consequences. Indeed, it must be noted that many pre War business cycle theorists focused their attention on precisely this possibility.

Perhaps a good jumping off point for such analyses might be the work of Knut Wicksell. He made the distinction between the "natural" rate of interest, which equalized saving and

\footnotetext{
${ }^{48}$ Even as of mid 2010, when bond yields were significantly higher than in early 2012, there were estimates that sustained low rates implied that "half of UK companies are bust". See Johnson (2010).

${ }^{49}$ Under proposals outstanding as of June 2012, companies will no longer be able to defer recognition of actuarial gains and losses. Currently, they can do so using the so called "corridor method". In addition, companies will no longer be able to assume a lower rate for discounting liabilities than the assumed rate (often unreasonably high) at which assets accumulate.

${ }^{50}$ The WEO, published by the IMF in the spring of 2008, predicted real growth in the advanced economies in 2009 of 3.8 percent of GDP. The actual outcome was -3.7 percent, a forecast error of 7.5 percentage points of GDP. They were by no means alone in missing this dramatic turnaround.

${ }^{51}$ For more on this see White (2010)
} 
investment plans, and the "financial" rate of interest, set by the banking sector. Were the natural rate to diverge from the financial (or market) rate set by the banking sector, prices would respond and a new equilibrium would eventually be reestablished at a different price level. Later thinkers in the Wicksellian tradition (the Austrians in particular) rather laid emphasis on the "possibility that a divergence of the market rate from the natural rate might have consequences beyond changing the price level". ${ }^{52}$ Referred to as "imbalances" in this paper, these consequences would eventually lead to a crisis of some sort if inflationary forces did not emerge first. Moreover, it has also been suggested the magnitude of any crisis would depend on the size of the accumulated imbalances, which would themselves depend on the size and duration of the differences between the two rates

Were we to adopt this analytical framework, policymakers today would seem to have serious cause for concern. For simplicity, suppose that the natural rate of interest (real) for the global economy as a whole can be proxied by an ex post measure; the potential rate of growth of the global economy, as estimated by the IMF. Reflecting globalization and technology transfer, this measure has been rising steadily for the last twenty years. In contrast, if one proxies the financial rate of interest (real) by an average of available breakeven rates (say for ten year TIPS), this measure has been falling for the last twenty years. Moreover, at the global level, the natural rate of interest rose above the financial rate in 1997, and the gap kept widening at least until the onset of the crisis in $2007^{53}$. From this perspective, underlying inflationary pressures and/or imbalances had been cumulating for many years before the crisis began.

Indeed, the magnitude of the crisis which began in 2007, and the lack of response in many AME's to macroeconomic measures to date, can also be viewed as evidence in support of using this kind of framework. In contrast to the ex post measure of the natural rate, assumed for simplicity above, most of those in the Wicksellian tradition assumed the natural rate was an ex ante concept, related to expectations about the future rate of return on capital. Evidently, as noted also by Keynes and his discussion of "animal spirits", these expectations could change quite dramatically over time. It could then be suggested that the (ex ante) natural rate collapsed in 2007, to a level well below the financial rate, as a direct result of the imbalances that had built up earlier. Moreover, given this particular way of thinking and noting that the financial rate is now constrained by the ZLB, this gap can only be redressed by raising the natural rate to encourage investment ${ }^{54}$. As discussed in Section $B$ b) above, this will not be an easy task.

\footnotetext{
${ }^{52}$ See Laidler (1999), p35

${ }^{53}$ See BIS (2007) and Hanoun (2012) Graph 4. Hanoun also provides evidence (Graph 5) that, for the last decade at least, the global policy rate has generally been well below the rate suggested by a global Taylor rule. For a description of the changes in central bank balance sheets, see Bank for International Settlements (2012), p40.

${ }^{54} \mathrm{~A}$ corollary of this would be that invested capital that was no longer profitable should be removed from production.
} 
The approach taken below is to identify possible "unintended consequences" of rapid credit and monetary growth, and then to evaluate whether such concerns would seem to be justified by the facts of recent developments and/or likely prospects for the future. Consistent with the discussion above, these concerns would include rising inflation and imbalances of various sorts. To be more specific, the latter would include misallocations of real resources (not only in credit upswings but also in downswings), undesired effects on the financial sector (not only bad loans but also unwelcome changes in financial structure) and rising income inequality. Evidently, interactions between these various imbalances could lead in principle to protracted recessions and even debt-deflation. Worse, rising income inequality could threaten social and even political stability.

\section{a) The likelihood of rising inflation}

Perhaps the first question to be addressed is how inflation was avoided in the AME's during the many years that "financial rates" were well below "natural rates" and credit growth was very rapid $^{55}$ ? One possible answer is that a growing commitment by central banks to the maintenance of low inflation succeeded in anchoring inflationary expectations. This explanation, however, is hard to reconcile with the objective fact of rapid monetary and credit expansion engineered by central banks over that period.

A more plausible (or at least complementary) explanation would be the major increase in the rate of growth of potential in the EME's, accompanied by a series of investment "busts" in a number of countries; Germany after reunification, Japan after the "bubble", South East Asia after the Asian crisis, and the US after the TMT crash of the early 2000's. In effect, a secular increase in global supply was met by a decrease in global demand with the predictable result of reducing inflation ${ }^{56}$. This provided the context in which easy monetary policies could be more easily pursued.

Looking forward, the likelihood of rising inflation in the AME's would seem to be limited. In most countries there appears to be a significant degree of excess capacity, and Section B above implies that ultra easy monetary policy is unlikely to remedy this problem quickly. Nevertheless, some sources of concern remain. In some countries, like the UK, exchange rate depreciation could have an impact on inflation. Crisis related reductions in the level of potential could also prove greater than is currently expected, ${ }^{57}$ leaving room for policy mistakes. Finally, a sudden shift in inflationary expectations, perhaps linked to further measures to extend ultra easy monetary policies, cannot not be completely ruled out. While inflation expectations show no trends (away from desired levels) in recent years, they do seem to have become more volatile.

\footnotetext{
${ }^{55}$ Alternative explanations for the "Great Moderation" are discussed at length in Borio and White (2003)

${ }^{56}$ A more detailed analysis is available in White (2008). See also Issing (2012) p10.

${ }^{57}$ The OECD estimates that the level of potential in the OECD countries fell after the onslaught of the crisis by about 3 percent on average. They stress, however, that these estimates are highly imprecise.
} 
A perhaps more pressing problem is the possibility of sharply higher inflation in EME's. In part due to their "fear of floating", many EMEs seem to be operating near full capacity, and monetary conditions are generally very loose. As well, the rate of growth of potential now seems to be slowing after previous sharp increases ${ }^{58}$. This could in turn, via the higher price of imports, lead to inflation accelerating unexpectedly in the AME's as well. In effect, this would be a reversal of the secular disinflationary impulses sent by EME's to the AME's in previous years. Since AME central banks underestimated the importance of the positive supply shocks in earlier years, it is not unlikely that they would also fail to recognize the implications of its reversal.

While such an inflationary outcome might be judged useful in resisting debt/deflation of the Fisher type, rising inflation along with stagnant demand in AME's would clearly imply other serious problems for the central banks of AMEs. On the one hand, raising policy rates to confront rising inflation could exacerbate continuing problems of slack demand and financial instability. On the other hand, failing to raise policy rates could cause inflationary expectations to rise. Further, were different central banks to respond differently, as they did in 2008 , there might also be unwelcome effects on exchange rates.

\section{b) Misallocations of real resources}

New books, articles in the popular press and even rap videos indicate that the Keynes-Hayek debate of the early 1930's is on again ${ }^{59}$. It remains highly relevant to the issue of whether ultra easy monetary policies might have unintended consequences. Keynes was fundamentally interested in demand side policies that would revive economies in a "Deep Slump". In contrast, Hayek and other members of the Austrian school were fundamentally interested in supply side issues. They rather focused on how the economy got into a "Deep Slump" in the first place, conscious of the possibility that remedies (more of the same) might actually make things worse over time.

The Austrian conclusion was that credit created by the banking system, rather than the on lending of genuine savings, would indeed spur spending but would also create misallocations of real resources ("malinvestments"). These supply side misallocations would eventually culminate in an economic crisis. Moreover, they concluded that the magnitude of the crisis would be

\footnotetext{
${ }^{58}$ As EME's begin to industrialize, they initially have the benefit of rapid urbanization (as agricultural productivity rises) and the international transfer of technology. Over time both of these "catch up " factors supporting growth become less important.

${ }^{59}$ It is important to note that the debate was with the Keynes of the "Treatise" and not yet the Keynes of the "General Theory". In the Treatise on Money, Keynes called for monetary authorities to take "extraordinary", "unorthodox" monetary policies to deal with the slump. Kregel (2011) p 1, contends that "The unorthodox policies that Keynes recommends are a nearly perfect description" of the ultra easy monetary policies followed in Japan, and more recently in other countries. Recall, as noted above, that Keynes' enthusiasm for such monetary measures had faded by the time of the General Theory.
} 
closely related to the amount of excess credit created in the previous upswing. Jorda, Schularick and Taylor (2012), using data from 14 AME's dating back to the 1870's, provide convincing empirical evidence that this intuition was essentially correct ${ }^{60}$. A similar conclusion arises from the historical data used by Reinhart and Reinhart (2010), and from recent US data based on differences in local market economic conditions ${ }^{61}$.

This conclusion does not, however, logically rule out the possibility that Hayek and Keynes were both "right". It is simply a fact that the economy does have both a demand side and a supply side. It is also a fact that policy actions do have both near term and longer term implications. Thus, demand side stimulus might well work to stimulate the economy in the near term, but such stimulus might come with a longer term price. Evaluation of the near term benefits and longer term costs of monetary stimulus is, in fact, the central theme of this paper.

In practice, Keynesian thinking has almost completely dominated the policy agenda for most of the post War period. Thus, the predominant consideration for policymakers ${ }^{62}$ has been the near term effects of monetary easing on aggregate demand, and the associated impact on inflation. Over the last two decades or so, with inflation near target levels or even threatening to fall below target, policymakers saw little need to raise interest rates in cyclical upturns. Similarly, there seemed no impediment to vigorous monetary easing in downturns.

Even within the Keynesian framework, however, these policies might now be thought questionable. As noted just above, the disinflationary trends observed in the global economy were in large part the result of positive supply shocks, rather than solely due to deficient demand. They should in principle have elicited a different and tighter response ${ }^{63}$. Viewed from an Austrian perspective, the policy error was even graver. Below the surface of the Great Moderation, such policies encouraged financial exuberance ${ }^{64}$ which allowed significant

\footnotetext{
${ }^{60}$ See also Reinhart and Reinhart (2011)

${ }^{61}$ Mian and Sufi (2011) relate the magnitude of local downturns in the US (primarily in the non traded sector) to the degree of household borrowing that built up in the same locality during the boom.

${ }^{62}$ Virtually all AME central banks give pride of place to a "first pillar"; namely their estimate of the output gap and its effect on inflation via an augmented Phillips curve. First the Bundesbank, but now also the ECB, have a "second, monetary" pillar which relates low frequency movements in monetary aggregates to longer term inflationary trends. This is still very different from looking at credit developments for their possible "unintended consequences", particularly on the supply side of the economy.

${ }^{63}$ There is a curious asymmetry here. It has been well accepted for decades that negative supply shocks, for example increases in energy prices pushing up inflation, need not cause policy rates to rise. The logic was that first round shifts in the price " level" could be tolerated if they had no second round effects on wages and "inflation". In contrast, positive supply shocks did in practice seem to lead to lower rates than otherwise. On this issue, see Beckworth (2008). Perhaps the clue to the asymmetry is that, in both cases, policy rates wind up lower than otherwise which tends to be both easy and popular.

${ }^{64}$ Issing (2012) notes (p3) that a combination of inflation targeting and supply side shocks can "turn policy into an independent source of instability...(It) fuels financial exuberance and financial exuberance in turn creates financial imbalances".
} 
"malinvestments" to build up in both phases of successive credit cycles. ${ }^{65}$ These developments are documented below.

\section{1) Misallocations in the credit upswing}

In a comprehensive review of pre War theories of business cycles, Haberler (1939) distinguished between two forms of "malinvestment" that arise in the upswing of the credit cycle: vertical and horizontal. Vertical malinvestments imply an intertemporal misallocation. It occurs when easy and cheap access to credit causes an inordinate shift towards capital investments, and particularly to longer lived capital investments. For the same reason, saving rates would be reduced and debts allowed to accumulate. These would eventually constrain future spending ${ }^{66}$ just at the time the increased supply potential was coming on line. Horizontal malinvestments are investments in particular sectors that eventually lead to excess capacity.

In both kinds of malinvestment, the eventual outturn is a collapse in profits. This results in the forced termination of further investment in projects already well advanced, less new investment in general, and an investment collapse in those particular sectors that had expanded the most during the credit upswing. Looking at developments over the last decade or so, it is very easy to find evidence of such processes at work.

First, consider vertical malinvestments. In the years of easy credit conditions preceding the onset of the crisis, investment in the housing stock in virtually every AME rose sharply ${ }^{67}$. House prices rose markedly, as did housing starts in most cases. The fact that these developments were unsustainable is now all too evident. In countries like the US, the UK, Spain and Ireland, the housing downturn is already well advanced, house prices continue to fall, and construction activity has slowed markedly. In some other countries (Canada, Sweden, Denmark, Norway etc.) house prices have continued to rise and construction activity remains elevated. Nevertheless, concerns about overbuilding in these countries are being expressed ever more forcefully ${ }^{68}$.

Similarly, in many EME's relatively easy credit conditions have also led to sharp increases in construction activity and in house prices. In many cases, not least China and Brazil, activity has focused on the production of "high end" properties which remain vacant after their purchase.

\footnotetext{
65 On returning from a visit to the US in the late 1920's, Hayek foretold a deep slump. On being told this was impossible, because US prices were essential stable, Hayek apparently responded that this was precisely the evidence of an underlying problem. Increases in productivity should have been pushing prices down, but credit expansion was holding them back up.

${ }^{66}$ In effect, savings would prove inadequate to purchase all of the goods and services provided by the increased investment generated artificially by credit received from the banking system.

${ }^{67}$ Among the AME's, only Germany, Switzerland and Japan failed to reflect these developments. In part, this was because all three countries were still recovering from their own, earlier, house price bubbles.

${ }^{68}$ Such concerns have been expressed in the various country reviews organized by the Economic and Development Review Committee of the OECD. Australia, New Zealand, Canada, the Scandinavian countries and a number of others all seem to be exposed in this regard.
} 
Given this overhang of inventory, it is not hard to believe that a downturn will prove inevitable. Since housing is long lived, cannot be readily used for other purposes, and is generally not internationally tradable, the effects of this particular kind of malinvestment could be felt for a long time.

Another example of vertical malinvestments would be the massive increases in infrastructure investment, largely privately financed, which occurred globally prior to the onset of the crisis. Indeed, in mid 2008, the Economist magazine called this infrastructure investment "the biggest boom in history" ${ }^{\prime 69}$. While this private sector boom came to a halt with the onset of the crisis, it was replaced in part by public sector spending on infrastructure. This has been most marked in China, where overall spending on investment since 2008 has hovered near 50 percent of GDP. Neither the private sector nor public sector phases of this investment boom would have been possible without ready access to relatively cheap credit. Indeed, in the Chinese case, the central authorities largely avoided fiscal expansion by explicitly ordering Chinese banks to provide the loans required by lower levels of government to meet their spending goals.

Large scale spending on infrastructure is not in itself a bad thing. In many circumstances, particularly in EME's, the social rate of return might be expected to well exceed the cost of financing. However, there is accumulating empirical evidence that many large infrastructure projects cost far more to build than originally estimated and produce far fewer benefits. Flyvbjerg (2009) gives many examples of large projects in AME's that would never have been built if ex post estimates of benefits and costs had been available. He cites the Channel Tunnel, the Danish Great Belt Tunnel, the "Big Dig" in Boston and the Millennium Dome among a host of others.

Flyvbjerg notes as well three global trends that increase the likelihood of infrastructure investments becoming "malinvestments". The first is the trend towards more rapid spending, driven by the exigencies of spending quickly during a downturn. This raises the risk of both waste and corruption. The second is the rising proportion of global infrastructure spending in EME's, given the presumption that governance of such projects might be even worse than in $\mathrm{AME}^{\prime} \mathrm{s}^{70}$. In China, for example, the dominant influence of the Communist Party on both borrowers and lenders is hard to reconcile with objective assessment of the net benefits of suggested projects. ${ }^{71}$ Third, infrastructure projects everywhere are increasingly dependent on

\footnotetext{
${ }^{69}$ The Economist (2008)

70 Flyvbjerg ultimately blames "bad governance" for these bad outcomes. In effect, those putting together projects consciously underestimate costs and overestimate benefits. They do this to make their projects more "competitive" with others in the search for funding, especially from governments.

${ }^{71}$ See McGregor (2010) for a broader discussion. For a more specific example, China is intent on building over 20000 kilometers of high speed rail tack to link up its major cities. At the same time, there is to be a massive expansion of airport service to the same destinations. Note as well, that many prestige projects favored by local governments are designed to "outdo" the projects of other local governments. This a recipe for overcapacity.
} 
IT and communications systems, where large projects have an even more dismal record of accomplishment than projects in other sectors.

A third example of vertical maladjustment, prompted by easy credit conditions, has been the massive build up of export capacity in many countries in South East Asia. Low interest rates in the importing AME's ensured high levels of consumption and ready markets. Conversely, in the exporting countries, low interest rates encouraged investment to satisfy those demands. Government commitment to "export led growth" strategies also implied resisting upward exchange rate pressures, and encouraged easier monetary policy in turn. Today, many of these exporting countries remain heavily reliant on sales to $A M E^{\prime} s^{72}$ whose debts are such that they can no longer afford to borrow to finance such sales.

A fourth and final example of vertical maladjustment is provided by the sharp drop in household saving rates over many years in a number of AME's, most notably in the English speaking countries. In many of these countries, house prices were rising rapidly during the period of rapidly expanding credit. Some households likely believed (wrongly) that they were in fact "wealthier" as a result, and spent more accordingly. In some countries, most notably the United States, higher house prices also provided more collateral to support further borrowing. Since in the early years of this century there were significant fears of inadequate demand and potentially even deflation, this borrowing was welcomed by policymakers as "intertemporal optimization". However, at the time, little or no attention was paid to the fact that such optimization would by definition require "payback" and could act as a serious constraint on growth in the future ${ }^{73}$.

The need for "payback" is most clearly evident in sharp increases in household debt service ratios in many countries ${ }^{74}$. These include the English speaking countries noted above, but also a number of "peripheral" countries in Europe as well. Further, perhaps linked to the "fear of floating" phenomena discussed above, many EME's now also have record high levels of household debt service to cope with. Such countries include some of the largest and fastest growing of the EME's; China, India, Brazil and Turkey in particular. While it is true that these increases in EME's have come off very low levels, the speed of the increase has been notable,

\footnotetext{
${ }^{72}$ This is not to deny successful efforts by a number of countries, including China, to expand markets in other EME's. Of course this still leaves the broader question of the robustness of the totality of those markets in the event of a serious downturn in the AME's.

${ }^{73}$ This problem is analogous to that faced by Japanese corporations in the 1990's, after many years of debt financed investment which proved unprofitable. Koo (2003) strongly contends that the weakness of investment spending in Japan in the 1990's was due to this "balance sheet effect", and was not due to a shortage of loans caused by a weakened banking system.

${ }^{74}$ See BIS (2012) p29 for a fuller documentation. Also see McKinsey (2010) who identify the household sector in five of the fourteen countries they consider as having a high probability of future deleveraging. They identify Spain, the US, the UK, Canada and Korea. While the household sectors in Brazil, Russia, China and India were not judged to be overleveraged, note that the data considered extended only to 2009. Thus the report missed the recent sharp increases in household debt levels in those countries.
} 
and might well have outpaced the capacity of the local financial systems to accurately estimate the capacity of borrowers to repay. Indeed by mid 2012, the percentage of non performing car loans in Brazil had already jumped sharply. Whether in AME's or EME's, the need for deleveraging by households adds a further reason to doubt that ultra easy monetary policy can sustainably stimulate the real economy.

Nor is it difficult to find evidence for the buildup of horizontal (sectorial malinvestments) during the last upswing of the credit cycle. The most obvious example is seen in the construction industry in many countries, mostly but not exclusively in the AME's. Evidently, this was closely related to the increased spending on housing and infrastructure referred to above ${ }^{75}$. Closely related, the financial sector also expanded very rapidly prior to the start of the crisis in 2007, before imploding immediately afterwards. The global automotive industry witnessed a massive increase in production capacity, not only prior to 2007, but also afterwards as automakers extrapolated past increases in sales in EME's far into the future. China in particular was estimated to have six million units of unutilized capacity in 2011 (twice the size of the German car market) ${ }^{76}$, with dealers also struggling with a huge increase in inventory. Finally, there was also a substantial increase in capacity in the renewable energy industry. As a result, the price of solar panels and wind powered turbines collapsed after the crisis began and many producers faced bankruptcy.

Beyond these increases in the global capacity to produce final goods and services, there were marked expansions in the capacity to produce intermediate and primary goods as well. Much of this was driven by developments in China where productive capacity was still expanding rapidly as of mid 2012 The steel and aluminium industries head a long list of sectors where overcapacity has been evident for a long time ${ }^{77}$. As for primary products, heavy investments have been made in Latin America, in Australia, and a number of other countries to produce and export basic commodities to support the development efforts in South East Asia. Should any link in this demand chain prove faulty, these investments in primary products could also prove much less profitable than is currently anticipated. Finally, there has been a commensurate increase in the capacity of the global distribution industry, not least container ships and bulk shipping, whose future could be similarly exposed.

\section{2) Misallocations in the credit downswing}

\footnotetext{
${ }^{75}$ Increased spending generally results in more production, but not necessarily. Supply responsiveness in the construction industry in fact varies widely across countries. For example, the response in terms of new housing starts was much greater in the US than the UK, due to the very strict planning and zoning restrictions in the latter.

76 See KPMG Global (2012)

${ }^{77}$ See European Chamber of Commerce in China (2009). In presenting the report, the President of the Chamber said "Our study shows the impact of overcapacity is subtle but far reaching, affecting dozens of industries and damaging economic growth, not only in China but worldwide". Note that this was written before the further spurt in investment spending in 2010.
} 
Economic downturns, whatever their cause, are always painful. Output that might have been produced is lost, and unemployment rises. Moreover, those less well off, often marginally attached to the work force, seem to suffer the most. This is the familiar Keynesian argument for using macroeconomic stimulus in such circumstances to raise aggregate demand ${ }^{78}$. However, as alluded to above, pre War economic theorists thought downturns also had some positive qualities. For those concerned about rapid credit expansion and "malinvestments", the downturn simply reveals the unsustainability of the previous expansion and its inevitable end. The downturn was then a time of necessary rebalancing with resources shifting from less productive to more productive uses. Schumpeter in particular stressed the opportunities which excess resources provided to entrepreneurs having new ideas and new products - the concept of "creative destruction". From this perspective, monetary policy choices in a downturn should again balance off short term benefits against longer term costs.

Consistent with the dominance of the Keynesian paradigm, monetary policy has been used with increasing vigor over the last quarter century to address prospective or actual downturns in the economy. For example, US monetary policy was eased significantly in 1987 after the stock market crash of October. It was further eased sharply in the early 1990's, after the property boom and the collapse of the Savings and Loan Associations. In spite of unemployment falling well below prevailing estimates of the US NAIRU, the US failed to raise rates in 1997 reflecting concerns about the possible global effects of the crisis in South East Asia. In 1998, the failure of LTCM led to explicit easing. This was followed in 2001 by an unprecedentedly vigorous monetary policy response to an impending slowdown, aggravated by the stock market crash and the events of September 11. Finally, beginning in 2007, monetary policy was further and dramatically eased in the various ways described at the beginning of this paper.

The following paragraphs will focus on the longer term, cumulative, effects of such policies. First, there is evidence that allowing malinvestments to persist can reduce potential growth rates. Second, it can be contended that the aggressive easing of policy in successive cycles led to serial "bubbles" of various sorts. In effect, these serial bubbles constrained the normal process through which malinvestments would have been purged in the course of a typical cyclical downturn.

The contention that easy monetary conditions lower the rate of growth of potential is not without counterarguments. On the one hand, some would contend that easy monetary conditions in a downturn help the reallocation of real resources from less to more productive industries $^{79}$. As well, if the economy recovers, then the accelerator mechanism can also lead to

\footnotetext{
${ }^{78}$ Recall, however, that Keynes' General Theory (1936) was directed to the issue of "Deep Slumps". It is not then clear that Keynes would have recommended similar policies in the face of actual small downturns, much less preventive easing to preclude even prospective downturns.

${ }^{79}$ See for example, Posen (2011)
} 
more capital investment ${ }^{80}$. These arguments, however, must also consider the various forces (considered above) that are currently acting to restrain investment. On the other hand, to the extent that low interest rates do discourage saving, capital accumulation will be discouraged over time. Very low "risk free" rates, dominated by the actions of central banks, can also mislead and contribute to costly misallocations. Moreover, it is possible that easy monetary conditions actually impede, rather than encourage, the reallocation of capital from less to more productive uses.

This last argument rests on the contention that banks will offer advantageous borrowing conditions to traditional customers in a downturn, even when they suspect they are insolvent. Peek and Rosengreen (2003) have investigated this phenomenon in Japan, and evidence of similar behavior has emerged in both the UK and continental Europe more recently. ${ }^{81}$ Such behavior on the part of banks is encouraged when they can borrow very cheaply, and also when they expect that easy money will lead to recovery and improved prospects for their clients. In effect, low interest rates encourage all the parties involved to gamble for resurrection.

"Evergreening" of this sort helps maintain the weak, the so called "zombie companies", who then continue to compete and drag down the strong. The Peek and Rosengreen study also documented how productivity growth suffered particularly in those industrial sectors most characterized by this kind of bank behavior. Moreover, the perceived need to support the weak could also lead to higher interest charges for those strong enough to afford it. Finally, it might also imply tighter credit conditions for potential new clients with new ideas as to how to adapt domestic supply to changing patterns of demand and foreign competition ${ }^{82}$. Since innovation is now seen as a primary driver of productivity growth (and thus potential) ${ }^{83}$, financial constraints of this sort would be particularly worrisome. And this would be even more the case in countries (In Europe and Japan) where banks remain the dominant source of finance.

The Governor of the Bank of Japan has repeatedly suggested that Japan's poor economic performance in recent decades has been largely due to a failure to adapt its production structure to the requirements of an aging population and the growing competitiveness of emerging Asian countries ${ }^{84}$. In contrast to his advice, and particularly since the onslaught of this current crisis, governments in many AME's have actually taken explicit measure like "cars for clunkers" and "short time working" to support existing production structures. Since the

\footnotetext{
${ }^{80}$ Summers and Delong (2012)

${ }^{81}$ See BIS(2012) p42 and 74, for a list of supporting references.

${ }^{82}$ With the rise of the EME's and their dominance of traditional manufacturing, some commentators even contend that AMEs need to develop a whole new, post industrial information economy. Evidently, if true, this would require a lot of financing.

${ }^{83}$ Assuming a Cobb Douglas production framework, "unexplained" movements in total factor productivity have for decades been the biggest driver of growth in most AME's. In recent years, the OECD has increasingly emphasized the importance of innovation in "explaining" movements in total factor productivity.

${ }^{84}$ Shirakawa (2012a,2012b)
} 
countries that used these programs the most actively were also running large current account surpluses at the time (eg: Germany, Japan, the Netherlands and Korea) it might also be suggested that many of the jobs "saved" in the short run will eventually disappear as global trade imbalances decline ${ }^{85}$. These policies were not only mistaken, in that they impeded longer run adjustment, but they were also fiscally costly. This raises the question of whether they might not have been under taken had the government's financing costs been higher at the time.

Finally, there is the issue of serial bubbles. Mention was made above of the successively more aggressive efforts made by central banks, since the middle 1980's, either to preempt downturns (eg: after the stock market crash of 1987) or to respond to downturns (eg; 1991, 2001 and 2008). What cannot be ignored is the possibility that each of those actions simply set the stage for the next "boom and bust" cycle, fuelled by ever declining credit standards and ever expanding debt accumulation. ${ }^{86}$

From the perspective of this hypothesis, monetary easing after the 1987 stock market crash contributed to the world wide property boom of the late 1980's. After it crashed in turn, the subsequent easing of policy in the AME's led to massive capital inflows into SEA contributing to the subsequent Asian crisis in 1997. This crisis was used as justification for a failure to raise policy rates, in the United States at least, which set the scene for the excessive leverage employed by LTCM and its subsequent demise in 1998. The lowering of policy rates in response, even though the unemployment rate in the AME's seemed unusually low, led to the stock market bubble that burst in 2000. Again, vigorous monetary easing resulted, as described above, which led to a worldwide housing boom. This boom peaked in 2007 in a number of AME's, seriously damaging their banking systems as well. However, in other AME's, the house price boom continues along with still rising and often record household debt ratios. This latter phenomena, as well as other signs of rising inflation and other credit driven imbalances in EME's $^{87}$, reflects the easy monetary policies followed worldwide in the aftermath of the crisis.

By mitigating the purging of malinvestments in successive cycles, monetary easing thus raised the likelihood of an eventual downturn that would be much more severe than a normal one. Moreover, the bursting of each of these successive bubbles led to an ever more aggressive monetary policy response. From a Keynesian perspective, this response seemed required to offset the effects of the ever growing "headwinds" associated with all the malinvestments noted above. In short, monetary policy has itself, over time, generated the set of circumstances in which aggressive monetary easing would be both more needed and also less effective. This

\footnotetext{
${ }^{85}$ In Europe the car industry was a particular beneficiary of such programs. It is already being recognized in France, Italy and Belgium that some auto plant closures are inevitable. The subsidiaries of foreign car firms operating in Germany might also be affected.

${ }^{86}$ George Soros (2010) has referred to this serial process as the "debt super cycle".

${ }^{87}$ For some interesting observations on recent developments in EMEs, see Hoffman (2012)
} 
conclusion seems even more justified when we turn to the implications of easy money for the financial sector.

\section{c) Effects on the financial sector}

Similar to the way that easy money in successive cycles encouraged imprudent borrowing, it also encouraged imprudent lending ${ }^{88}$. There are a number of dangers associated with this. The first of these would be that lenders suffer losses severe enough to cause an eventual and marked tightening of credit conditions. This could occur spontaneously, helping precipitate an economic slowdown, or could follow upon an economic slowdown (led from the demand side) that significantly raised loan losses. Tighter credit conditions would feed back on the real economy, aggravating the downturn. There seems clear evidence of such phenomena today, and also in the historical record ${ }^{89}$.

A second concern would be that easy monetary conditions, in association with regulatory and technical developments, would encourage over time the development of a "shadow banking sector" based less on traditional banking relationships and more on collateralized lending. Again, there is clear evidence of such an expansion in recent years. Since this kind of lending seems to be even more procyclical than traditional bank lending, and subject to other risks as well $^{90}$, this would have to be thought of as another unintended consequence of easy monetary conditions. A third concern is that insurance companies, and other lenders, might find it increasingly difficult to earn adequate returns on their assets. This could again imply longer term problems for an important part of the financial sector.

\section{1) Banks and shadow banking in the credit upswing}

The mainstay of traditional banking is to borrow short and lend long. With policy rates low relative to longer term rates, and relative to rates incorporating a counterparty risk premium, banks have an incentive to create credit as the demand for credit increases. The rate of growth of credit in the AME's and the EME's between 2003 and 2007 was well above the respective growth rates of nominal income.

Moreover, there is growing evidence that banks and financial markets more generally can become overly optimistic about the risks that they run in their lending practices. Recent BIS Working Papers by Borio and Zhu (2008), Gambacorta (2009), Disyatat (2010) and Altunbas et al (2010) all provide evidence of the importance of what they call the "risk taking channel" of the transmission mechanism of monetary policy ${ }^{91}$. Tobias and Shin (2008a and 2008b) also provide

\footnotetext{
${ }^{88}$ For a fuller analysis of how expanding "safety nets", not least monetary easing in downturns, have contributed to moral hazard on the part of both lenders and borrowers, see White (2004).

${ }^{89}$ Reinhart and Rogoff (2009) p145

${ }^{90}$ For a fuller assessment, see Financial Stability Board (2012)

${ }^{91}$ Also see Maddaloni and Peydro (2010)
} 
compelling evidence that "Short term interest rates are determinants of the cost of leverage and are found to be important in influencing the size of financial intermediary balance sheets". In addition, Adrian and Shinn establish an empirical link between higher leverage, induced by lower interest rates, and subsequent growth rates of housing investment and durable goods consumption.

More anecdotal evidence also supports the hypothesis that low rates encourage more risk taking and softer lending standards. In the years leading up to the crisis which broke in 2007, lending standards dropped almost everywhere, with subprime mortgages to households and covenant light loans to corporations being the most egregious examples. Similarly, there were sharp declines in the sovereign spreads of EME's and of lower rated corporate and financial paper. Beginning in the middle of 2003, when policy rates in the AME's were at their lowest level, the prices of houses in many countries, as well as the prices of other illiquid assets (including commodities), began to rise sharply. Similarly, the cost of insurance against unexpected events (proxied by the Vix index) fell to record low levels. In sum, illiquidity was in high demand and liquidity was for sale cheaply. All of these trends were consistent with a credit driven expansion fostered by low policy rates. ${ }^{92}$

Credit expansions of this sort, if not restrained by sufficiently high policy rates, eventually run into two other constraints. The first of these is a shortage of capital, which results in leverage ratios rising to uncomfortable levels. The second is a shortage of longer term and reliable funding to support the credit expansion. Indeed, Kaminska (2012) contends that this latter problem is a "terminal disease" affecting banking, and was greatly aggravated by the secular fall in interest rates ${ }^{93}$. However, banks took aggressive steps to confront both problems, thus allowing them to continue to meet the demand for credit expansion promoted by low borrowing costs. As noted above, this implied a deeper eventual downturn than otherwise given both larger "malinvestments" and also a structurally weakened financial sector.

Banks first confronted the capital shortage problem by exploiting opportunities for regulatory arbitrage opened up by the introduction of "risk weighted assets" in the first Basel Accord of

\footnotetext{
${ }^{92}$ A puzzle is why increases in policy rates, in the US in particular between mid 2004 and 2007, failed to stop the excesses. Two reasons suggest themselves. First, the dynamic of the boom was so great that the "measured" increase in policy rates (essentially 25 basis points per meeting) was inadequate to offset the expected gains. Second, because the increases in policy rates were so well telegraphed, the risks involved in leveraged positions were declining even more than the spread was narrowing. With the Sharpe ratio rising, there was a positive invitation to take on even more leverage. Adrian and Shin (2008) seem to take this point seriously. They state (p28) "If central bank communication compresses the uncertainty around future short rates, the risk of taking on longlived assets financed by short term debt is compressed. ........ In this sense, there is the possibility that forward looking communication can be counterproductive." This point was also made repeatedly in BIS Annual Reports prior to the beginning of the crisis.

${ }^{93}$ Kaminska (2012), p.3 "The consequences of falling yields were, after all, potentially deadly for banks if mismanaged. Not only did they threaten the margins banks collected via cheap liabilities, they increasingly compromised funding supply altogether."
} 
1992. Slovik (2011) investigates the behavior of 15 of the largest systemically important banks in the AME's. He documents how the ratio of risk weighted assets to total assets fell almost monotonically from 70 percent of GDP in 1992 to just 35 percent just prior to the onset of the crisis. The implication he draws is that large banks, stretching back over two decades, have been drawing back from their traditional line of business; namely "to actively search for and evaluate lending opportunities and advance loans to credit worthy enterprises and households" ${ }^{\prime 4}$. Instead, large banks have increasingly pursued a different business model, based on "shadow banking", which promised to alleviate both the capital problem and the long term funding problem simultaneously.

The essence of shadow banking is to make loans, securitize them, sell the securities and insure them, and actively trade all the financial assets involved ${ }^{95}$. In effect, traditional relationship banking is replaced by a collateralized market system with the repo market at its heart. Banks thus get risky assets off the balance sheet, reducing the constraints just noted, while providing a rich source of fees and further profits from market making and proprietary trading. However, while seemingly convenient to the financial institutions involved, shadow banking activities have significant externalities (or systemic risks) for the financial system as a whole.

A recent report by the Financial Stability Board (2012) enumerates many of these risks. Not least, is the complexity and inherent non transparency of "shadow banking" - thus its name. With long chains of interactions involving collateral, rehypothetication ${ }^{96}$ and large offsetting positions in CDS and other derivatives, exposure to counterparty risk became almost impossible to estimate. In association with the belief (likely justified) that many of the firms at the heart of the system are "too big and/or complicated to fail", these attributes effectively precluded the exercise of market discipline to reign in excessive risk taking. As well, the opacity of the system proved a substantial impediment to supervisory oversight. Shortcomings in this regard, with macroeconomic implications, have been documented by Blustein (2012) as well as the Independent Evaluation Office of the IMF (2011). Shortcomings at the microeconomic level are attested to by the recent number of criminal investigations into unacceptable kinds of financial behavior. $^{97}$

\footnotetext{
${ }^{94}$ Slovik (2011) p.6. To put this otherwise, the ratio of total loans to total assets for Deutsche Bank fell from 85 percent in 1990 to 27 percent in 2010. For UBS the decline was from 78 percent to 22 percent, and for Bank of America from 58 to 42 percent. See Slovik Table 1.

${ }^{95}$ The most comprehensive description can be found in Pozsar et al (2010). Also Financial Stability Board (2012)

${ }^{96}$ This element of market practices in not well known. Assets received as collateral by a lender are frequently lent out or used as collateral by the lender to borrow more funds. Known as "rehypothecation", this practice makes the chain of related transactions still longer and more complicated. See Singh and Aitken (2009) for a seminal discussion.

${ }^{97}$ Consider recent cases of insider trading, money laundering and the setting of LIBOR. However, Kindelberger and Aliber (2005) remind us that fraud and criminality were late- credit- cycle phenomena long before the rise of shadow banking.
} 
Equally important, a point made by the FSB as well as Adrian and Shin (2008a and 2008b) and Geanakoplos (2003 and 2010), is that a collateral based lending system tends to be highly procyclical in its operations. Essentially this is because the value of available collateral reflects three components; the market value of the collateral, the haircut imposed on the borrower and the velocity of turnover (rehypothecation)of the available collateral ${ }^{98}$. All three of these are likely to move highly procyclically, a tendency documented using recent data by Garcia (2012) and Singh (2012). Further, later in the credit upswing, whole classes of collateral can be judged "acceptable" that would not previously have been so considered. Indeed, as Rajan (2005) has pointed out, substantial efforts were made to construct new instruments (like CDO's and their variants) that looked less risky in that the Probability of Default seemed to have fallen. The fact that the Expected Loss had not fallen commensurately, because the Loss Given Default had risen, given the nature of the new instrument, was generally ignored ${ }^{99}$.

Finally, the way the shadow banking system has evolved implies that the end of the "boom" phase can occur very precipitously. Longer term lending tends increasingly to depend on short term funding. Because such funds are not covered by deposit insurance schemes, "runs" can occur quickly when confidence erodes in the solvency of the counterparts. In effect, the famous "Minsky moment" is likely to be shorter, harder to predict, and even more self fulfilling than Minsky suggested. The failure of Bear Sterns and Lehmans provide good examples of these dangers. As well, the shadow banking system has an increasingly international flavor. This not only reduces transparency and the quality of regulatory oversight, but also produces a degree of "balance sheet" exposure that could easily precipitate or aggravate foreign exchange crises. Concerns of this nature have been raised by Obstfeld (2010), Borio and Disyatat (2011) and Shin (2011).

To sum up, low policy rates encourage imprudent behaviour on the part of lenders during the credit upswing. Moreover, they have also contributed to structural change within the financial sector that makes it inherently more procyclical and also less likely to respond to monetary easing in the future. As with induced changes in the behavior of borrowers, low policy rates have themselves generated circumstances for lenders in which aggressive monetary easing would be more needed but also less effective.

\section{2) Banks and shadow banking in the credit downswing}

Whatever precipitates the end of the credit upswing, the downswing will be characterized by a reversal of all the forces that previously made credit so easily available. Losses will have to be

\footnotetext{
${ }^{98}$ Singh (2011) provides evidence of how this practice fluctuates with the credit cycle.

99 This is consistent with the hypothesis of psychologists that most humans suffer from "disaster myopia". This could be the result of survival strategies becoming hard wired over millions of years of evolution.
} 
absorbed, affecting profits and capital ${ }^{100}$. The appetite for risk will decline, as will the value of collateral as market prices fall, haircuts rise and rehypothecation slows. Worse, whole classes of collateral (like CDO's and the bonds of peripheral countries in Europe) will be judged unacceptable by lenders. Instead, they will accept as collateral only the bonds of the highest ranked sovereigns, and even then only for short term loans. Perhaps still worse, uncollaterized lending (say unsecured bond issues by banks) could become almost unavailable.

To say that financial institutions now face capital losses and severe funding challenges is to say that the very problems they tried to avoid, through the shadow banking mechanism, have now reappeared in a particularly virulent form. Moreover, they must be confronted, not at a time of vigorous economic expansion, but rather of contraction. This implies that both the cost of capital and the cost of funding (relative to policy rates) are likely to be higher. From a secular viewpoint, the implied need to deleverage might be thought a welcome reaction to excessive leverage earlier on ${ }^{101}$. However, from a cyclical perspective, the worry would be a sharp tightening of credit conditions for ultimate borrowers that would reduce their capacity to spend and deepen the downturn.

There seems little question that the financial systems of most AME's face particular challenges at the present time. The situation is perhaps worst in Europe reflecting factors considered just below. While the problems of European banks are highlighted, the interdependencies implicit in shadow banking imply that financial systems in other continents might also be deeply affected by possible European developments. Unfortunately, this is in the realm of uncertainty rather than quantifiable risk.

To explain the particular challenges facing European banks, consider first the degree of imprudent lending of core Eurozone banks to the banks of peripheral countries. These loans reflected the fallacious belief that there could be no balance of payments problems within the euro zone. Closely related, European banks prior to the crisis had raised large sums in short term dollar loans and used them to make longer term dollar loans through the shadow banking system. Finding dollars to fund those positions subsequently proved particularly difficult, as money market mutual funds in particular withdrew funding. ${ }^{102}$. Second, regulatory efforts to tighten capital and liquidity standards during the credit downswing have materially complicated the situation. Recall that most of the measures being implemented now were suggested under Basel 3. However, they were originally scheduled to be brought in only much later, in order to cushion the effects on a still recovering economy. Third, the evolving euro zone crisis, with its

\footnotetext{
${ }^{100}$ Financial institutions can for a time (perhaps a long time) avoid this by making new loans to cover interest payments ("evergreening"). Low interest rates encourage such behavior. Since the crisis began, loan default rates in Europe have been unusually low. See Bank for International Settlements (2012) Graph VI.1

${ }^{101} \mathrm{~A}$ body of literature is now emerging which suggests that, beyond certain levels of credit to GDP, financial deepening actually slows potential growth. See Cecchetti and Kharroubi (2012)

102 McGuire and Goetz ( 2009)
} 
implications for indebted sovereigns and even the survival of the euro, have raised further questions about the future of European banks.

How are financial institutions now responding to the shortage of capital, longer term funding and the shortage of acceptable collateral? As for capital, many banks have cut costs and retained more of the resulting profits. A few have issued new equity. Unfortunately, there also seems to have been a significant effort to reduce capital requirements by manipulating risk weights using internal models. As for longer term funding and the particular problem of collateral, many banks have been highly innovative in "collateral mining" in an attempt to obtain or create new collateral that lenders will think of as being safer. Collateral swaps between banks and insurance companies, better constructed CDO's, greater issuance of ETF's, issuance of covered bonds, and reliance on funding from corporations in the repo market are all increasing. Unfortunately, each of these alternative sources of funds also has significant risks associated with it ${ }^{103}$, not least that the collateral offered could be significantly less safe than it first appears to be.

The bottom line thus remains. The poor health of the financial system in AME's, arising from the earlier period of low rates and rapid credit expansion, could add materially to the headwinds facing the global economy. As noted above, rising funding costs have implied that bank lending rates have fallen significantly less than policy rates. In many countries, especially peripheral countries in Europe, lending standards have tightened significantly. Small and medium size enterprises everywhere have been the most affected, as have borrowers in areas dominated by community banks whose lending generally lacks diversification

Short of a wholesale restructuring of the liabilities of financial institutions (linked to recognizing losses on the asset side of the balance sheet), it is not clear what central banks can to do to restore the financial system to health. If the problem is insolvency and fears of insolvency, the provision of still more liquidity only postpones the day of reckoning ${ }^{104}$. Indeed, if the central bank lending is done only against "good collateral", the collateral shortfall problem will be exacerbated especially since central banks do not in general rehypothecate ${ }^{105}$.

As for still lower policy rates to help the financial system, this might temporarily raise lending spreads and profitability. However, over time, spreads (both term and credit) will trend back

\footnotetext{
${ }^{103}$ The Bank of England is concerned about collateral swaps and ETF's. See Hughes (2011). On ETF's, also see Raswamy(2011). On the limitations of the issuance of covered bonds, see Alloway (2012a) and Alloway (2012b). While it seems there continues to be scope for more covered bond issues at present, the concern remains that there will eventually be a "tipping point". Because covered bonds subordinate other lenders, they might in the end cause uncovered lending to stop entirely.

${ }^{104}$ In the Introduction to this paper, explicit debt restructuring is suggested as one of the policies that governments might follow that would actually encourage recovery.

${ }^{105}$ Declining liquidity in the longer term US Treasury market has been ascribed to "Operation Twist". Similar comments have followed on large scale purchases of gilts by the Bank of England.
} 
towards normal levels as longer term assets mature. Indeed, in the aftermath of a financial crisis, the search for safety along with tightened regulatory standards might result (in some countries) in abnormally sharp declines in term spreads due to declines in longer term government bond rates ${ }^{106}$. Against this background, policies like the Fed's so called "Operation Twist", which artificially reduce term spreads, also reduce the willingness to lend long even if the desire to borrow increases. ${ }^{107}$ And, finally and likely most important, still lower policy rates threaten still more of the unintended consequences which brought us the current crisis in the first place.

\section{3) Other unintended consequences in the financial sector}

Given the unprecedented character of the monetary policies followed in recent years, and the almost complete absence of a financial sector in currently used macroeconomic models, there might well be other unintended consequences that are not yet on the radar screen. By way of example only, futures brokers demand margin, and customers often over margin. The broker can invest the excess, and often a substantial portion of their profits comes from this source $^{108}$. Low interest rates threaten this income source and perhaps even the whole business model. A similar concern might arise concerning the viability of money market mutual funds, supposing that asset returns were not sufficient to even cover operating expenses. A final example of potential problems has to do with the swaps markets, where unexpectedly low policy rates can punish severely those that bet the wrong way. This could lead to bankruptcies and other unintended consequences. ${ }^{109}$

A problem which has been far better recognized is the implications of low interest rates for insurance companies ${ }^{110}$. This issue was flagged at least as far back as $2000^{111}$, but in recent years a wide range of studies into this problem have been carried out ${ }^{112}$. Ernst and Young estimate that the top 25 life companies would see net investment income decline by 51 basis points (from a 2010 level of 5.01 percent) if interest rates remained at the level of October 2011 for three years. Companies would be most affected when heavily invested in bonds, when the duration of the assets was short (relative to the duration of liabilities), and when

\footnotetext{
${ }^{106}$ The flattening of yield curves has already led to a narrowing of interest spreads. See Bank for International Settlements (2012) Table VI.1

${ }^{107}$ See Bill Gross (2012). This is particularly pernicious if it thwarts longer term lending to fund the longer term investment that many AME's really need.

${ }^{108}$ See Meyer (2012)

${ }^{109}$ See Haddock and Barnes (2012). They contend that, prior to 2007, many highly leveraged property deals in the UK used swaps to minimize the risks of rising financing rates. Indeed, many of these swaps had a maturity longer than the underlying loan itself. Now many of these deals need to be restructured, but low policy rates have raised the cost of breaking the swap to prohibitive levels. This is another example of how low policy rates can impede the purging of malinvestments in the downswing of the credit cycle.

${ }^{110}$ These are very similar to the implications for pension funds which were discussed above.

${ }^{111}$ Dickson (2001)

${ }^{112}$ Antolin et al (2011), French et al (2011), Standard and Poors (2011) and Ramaswamy (2012)
} 
companies had little room to maneuver on the liability side because of previous contractual agreements.

Such a decline in portfolio returns is significant and has already led to certain reactions on the part of the insurance companies most affected. Variously, dividends have been lowered, premia have been raised, payouts to the insured have been reduced (where possible), and companies have withdrawn from business lines that no longer seem possible. In conducting an assessment of the problems faced, and the reactions to date, Standard and Poors said that it saw no need to change ratings "in the near term". This is comforting.

However, left unassessed were three other risks that could prove important. First, what would be the effects of interest rates staying low for much longer than the next two to three years? Second, how might this interact with calls for more capital and expensive, new monitoring procedures in companies judged to be of systemic importance? Third, and closely related, what is the likelihood that some insurance companies might gamble for resurrection by substantially increasing their risk taking. Evidently this is a possible outcome not just confined to insurance companies, but to all financial institutions who suffer losses in a low interest rate environment $^{113}$. Unfortunately, it is generally impossible to assess this possibility until such risks actually materialize. By then the damage, perhaps systemic, has already been done.

\section{d) Effects on central banks and governments}

Ultra easy monetary policies, whether very low policy rates or policies affecting the size and composition of their balance sheets, can also have unintended and unwelcome implications for central banks themselves. Some of these effects are more technical. First, with very low policy rates, the likelihood rises that normal intermediation spreads in private markets will fall so far that these markets will collapse. The central bank may then find itself as the "market maker of last resort". The current interbank market might fall into this category. Moreover, a similar experience in Japan in the 1990's indicates that restarting such private markets is not easy. Second, deeper questions can arise about central banks operating procedures in such an environment ${ }^{114}$. Third, with central banks so active in so many markets, the danger rises that the prices in those markets will increasingly be determined by the central bank's actions. While there are both positive and negative implications for the broader economy, as described in earlier sections, there is one clear negative for central banks. The information normally provided to central banks by market movements, information which ought to help in the conduct of monetary policy, will be increasingly absent. Finally, with policies being essentially

\footnotetext{
${ }^{113}$ For a discussion of the trading losses recently suffered by J P Morgan, see Tett (2012)

${ }^{114}$ See Bank for International Settlements (2012) Box IV b.
} 
unprecedented, wholly unexpected implications for central banks (as with others) cannot be ruled out ${ }^{115}$.

Beyond these technical considerations, the actions undertaken by AME central banks pose a clear threat to their "independence" in the pursuit of price stability. First, as central banks have purchased (or accepted as collateral) assets of lower quality, they have exposed themselves to losses. If it were felt necessary to recapitalize the central bank ${ }^{116}$, this would be both embarrassing and another potential source of influence of the government over the central bank's activities. Second, the actions of central banks have palpably been motivated by concerns about financial stability. Going forward, it will no longer be possible to suggest that monetary policy can be uniquely focused on near term price stability. Third, by purchasing government paper on a large scale, central banks open themselves to the criticism that they are cooperating in the process of fiscal dominance ${ }^{117}$.

It is easier to identify these possible implications for central banks than to assess their desirability. On recapitalization, it is not at all clear that central banks need positive capital to carry out their responsibilities ${ }^{118}$. On central banks being overly concerned with financial stability, many economists would argue that this was part (indeed the core) of the traditional mandate of central banks. They would note that, since financial instability can lead to deflation (which is not price stability either), the concerns about price and financial instability are simply two sides of the same coin ${ }^{119}$. Adrian and Shin (2008) even insist that the link is growing ever stronger, given how policy rates drive the leverage cycle in the modern world of shadow banking. Finally, suppose that central bank purchases of government paper are a response to a market driven "run" that could become self fulfilling ${ }^{120}$. Is this not exactly the kind of situation

\footnotetext{
${ }^{115}$ In mid 2012, some commentators suggested the ECB should start paying negative interest rates on reserves held at the ECB. The initial ECB resistance to this suggestion was based in part on this concern. Another worry, arising from recent Danish experience, was that banks would then have to recoup losses by raising rates on loans. In this way, monetary easing might prove contractionary.

${ }^{116}$ Leijonhufvud (2009)makes the related point that, in choosing who to support and who not, central banks are making choices with distributional implications. Issues of distribution fall more normally in the realm of politics and will attract the attention of politicians.

${ }^{117}$ Hanoun (2011) expresses concern that the focus of central banks on price stability will be diluted by financial dominance, fiscal dominance and also exchange rate dominance. This last concern refers to the "fear of floating", referred to above, that has extended the credit driven problems in the AME $s$ to the EMEs as well.

${ }^{118}$ The central banks of many countries have operated with negative capital for decades; e.g., Chile, Jamaica and others.

${ }^{119}$ This author, and Borio and others at the BIS, have been making this point for many years. The practical implication is that price stability targets should extend over a horizon long enough to allow imbalances to unwind. Thus, to lean against a credit bubble is to lean against some combination of possible near term inflationary pressures and/or the possibility of excessive disinflation (or even deflation) over the medium term. See White (2006a). Operationally, this implies that separating the price stability function from the financial stability function at central banks is logically wrong. See White (2012a). Issing (2012) reminds us, however, of some important political considerations that could qualify this conclusion.

${ }^{120}$ The problem is one of multiple equilibria. A sovereign may be solvent given reasonable interest rates, but not if a run pushes up rates beyond some limit.
} 
when central banks ought to intervene? Evidently, such considerations are receiving a great deal of attention in the context of the Eurozone crisis.

What are the implications of ultra easy monetary policy for governments? One technical response is that it could influence the maturity structure of government debt. With a positively sloped yield curve, governments might be tempted to rely on ever shorter financing. This would leave them open to significant refinancing risks when interest rates eventually began to rise. Indeed, if the maturity structure became short enough, higher rates to fight inflationary pressure might cause a widening of the government deficit sufficient to raise fears of fiscal dominance. In the limit, monetary tightening might then raise inflationary expectations rather than lower them. While this dynamic was seen in the past in some Latin American countries, in this crisis the maturity structure of the debt in many AMEs has actually been lengthened not shortened.

A more fundamental effect on governments, however, is that it fosters false confidence in the sustainability of their fiscal position. In the last few years, in spite of rising debt levels, the proportion of government debt service to GDP in many AME's has actually fallen. Citing as well the example of Japan, many commentators thus contend that the need for fiscal consolidation can be resisted for a long time. Koo, Martin Wolf of the Financial Times, and others are undoubtedly right in suggesting that a debt driven private sector collapse should normally be offset by public sector stimulus. What cannot be forgotten, however, is the suddenness with which market confidence can be lost, and the fact that the Japanese situation is highly unusual in a number of ways ${ }^{121}$.

What is clearer is that exiting from a period of ultra easy monetary policy will not be easy. In this area, the Japanese experience over the last two decades is instructive. Central banks using traditional models will hesitate to raise rates because growth seems sub-normal. Further, the recognition that higher short rates might cause longer rates to "spike", with uncertain effects on financial stability, will also induce caution ${ }^{122}$. Governments will also firmly resist higher rates, because they might well reveal that the level of government debt had indeed risen to unsustainable levels. Further, on the basis of recent experience, the entire financial community (with its formidable capacity for public communication and private lobbying) will oppose any tightening of policy as too dangerous. Their motives in this regard are questioned below. Presumably a sharp enough increase in inflation would lead to a tightening of policy. However,

\footnotetext{
${ }^{121}$ The Japanese crisis of the 1990's began with a very high household saving rate, a very strong home bias for portfolio investment and the world's largest trade surplus. Contrast this, for example, with the almost opposite position of the US today. A marked shift in market confidence in US Treasury debt would then seem likely to lead to a dollar crisis as well.

${ }^{122}$ This might be particularly the case in the US. Recall the turmoil in the bond markets when rates were raised in 1994. Recall as well the concern to avoid financial instability implicit in the "measured" increase in policy rates between 2004 and 2007. Further, because of the problem of convexity hedging, which is unique to the United States, there might well be concerns that raising policy rates could have undesired consequences.
} 
by then a lot of further damage - not least to the credibility of central banks - might well have been done.

\section{e) Effects on the distribution of income and wealth}

Income inequality has risen sharply in almost every country in the world in recent years. This applies equally to AME' and EME's ${ }^{123}$. Moreover, after many years when distributional issues were largely ignored, these trends are now receiving increased attention. While arguments can easily be made for some degree of inequality to foster growth ${ }^{124}$, there is a sense almost everywhere that recent trends have gone too far. Wilkinson and Picket (2009) suggest that greater inequality has many undesirable social effects. It has also been suggested that greater inequality can leads to a concentration of political power in the hands of those who wish to use it for their own purposes. In the limit, such trends call into question the legitimacy of the whole democratic process. Further, by raising perceptions of unfairness, the trust that underpins all transactions in a market system can also be eroded. Evidently, these are crucially important social issues.

Given its global incidence and secular character, rising income inequality is likely deeply rooted in technological change and globalization, both of which threaten the less well educated. Nevertheless, it is also worth asking whether, to some degree, this might be another unintended consequence of ultra easy monetary policy. Not only has the share of wages (in total factor income) been declining in many countries, but the rising profit share has been increasingly driven by the financial sector. It seems to defy common sense that ane point 40 percent of all US corporate profits (value added?) came from this single source.

To simplify a description of how such a process might work, distinguish between three classes of people. Class 1 (entrepreneurs and financiers) are those who are rich enough to save (equity) and they invest on a leveraged basis using funds borrowed from other savers. This second class of savers (Class 2 ) is also relatively well off, but more risk adverse than the first class. Class 3 consists of the less well off who essentially borrow from the others. It is of interest to see who fares relatively well (and relatively badly) in the "boom bust" phases of the credit cycle, and also how shadow banking practices play into this. As argued above, both constitute the unexpected consequences of ultra easy monetary policies.

In the boom phase of the cycle, with interest rate low relative to expected rewards, members of Class 1 speculate, using leverage, and generally make substantial profits as asset prices rise and the economy expands. The momentum of this process continues even after policy rates begin to rise. Speculation is also encouraged by the safety net features increasingly provided by

\footnotetext{
${ }^{123}$ See OECD (2011)

${ }^{124}$ The classical argument is that richer people save more and this provides the basis for capital accumulation.
} 
governments $^{125}$. Moreover, those in the financial sector systematically exploit knowledge asymmetries to increase both fees and gains from market movements. This process of extraction is facilitated by the inherent non transparency of the shadow banking system. Finally, members of Class 1 use their political influence to enhance these safety net features and to drum up support for the "safety and soundness" of the shadow banking system upon which they increasingly rely ${ }^{126}$.

Members of Class 2 also profit, especially as interest rates rise, since they are net savers (creditors) with predominantly short term assets. Class 3 members suffer from higher interest rates as the recovery continues, but to the extent they have borrowed to buy real assets (especially houses) they also seem to gain as the prices of those assets rise. Rajan (2010) contends that governments actively encouraged this process ${ }^{127}$ to allow lower income people to continue to consume, even as their incomes and job prospects were being further squeezed by technological developments and globalization.

In the bust phase of the cycle, asset prices collapse and Class 1 speculators can lose part (though rarely all) of the wealth accumulated earlier. Sharply easier monetary conditions ease their burden materially. Again, there is lobbying to ensure that the other forms of support promised earlier by governments actually materializes. Members of Class 2 bear the main burden of this transfer from creditors to debtors, either directly (as their financial assets earn very little) or indirectly due to lower pensions and higher insurance cost. As debtors, members of Class 3 also benefit from ultra easy monetary policy ${ }^{128}$. Overall, however, they suffer the most because their net wealth is very low, their access to further credit disappears, and they are the most liable to lose their jobs in the downturn. Ironically, if Rajan's thesis is correct, the policies originally designed to help the poor have hurt them the most.

This story is highly stylized and perhaps not true in certain respects. Nevertheless, it seems true enough to warrant further interdisciplinary research into the potential redistributive implications of ultra easy monetary policy.

\section{Conclusions}

\footnotetext{
${ }^{125}$ These would include the "Greenspan put", and the assumption that some firms were too $\mathrm{big} / \mathrm{complex} /$ interrelated to be allowed to fail. Another important advantage is that lenders in the US and EU, with loans secured on financial collateral, have bankruptcy privileges. That is, in the case of bankruptcy, the holders of collateral can immediately seize it and sell it, thus jumping the normal queue of creditors. See Perotti (2012) and Johnson R (2010). Fisher and Rosenblum (2012) and others feel that banks that cannot be allowed to fail in a disorderly fashion should be broken up. Needless to say, this suggestion has proven controversial.

${ }^{126}$ For two powerful works speaking to these issues, see Johnson S (2009) and Wedel (2009)

${ }^{127}$ In the US, the massive expansion of the remit of Government Sponsored Enterprises (especially Fannie Mae and Freddie Mac) provide strong support for Rajan's position.

${ }^{128}$ This would be limited, however, if the mortgage were fixed rate and long term. In the US, refinancing opportunities would also be restricted if the value of the property fell below the value of the mortgage.
} 
The case for ultra easy monetary policies has been well enough made to convince the central banks of most AMEs to follow such polices. They have succeeded thus far in avoiding a collapse of both the global economy and the financial system that supports it. Nevertheless, it is argued in this paper, that the capacity of such policies to stimulate "strong, sustainable and balanced growth" in the global economy is limited. Moreover, ultra easy monetary policies have a wide variety of undesirable medium term effects - the unintended consequences. They create malinvestments in the real economy, threaten the health of financial institutions and the functioning of financial markets, constrain the "independent " pursuit of price stability by central banks, encourage governments to refrain from confronting sovereign debt problems in a timely way, and redistribute income and wealth in a highly regressive fashion. While each medium term effect on its own might be questioned, considered all together they support strongly the proposition that aggressive monetary easing in economic downturns is not "a free lunch".

Looking forward to when this crisis is over, the principal lesson for central banks would seem to be that they should lean more aggressively against credit driven upswings, and be more prepared to tolerate the subsequent downswings. This could help avoid future crises of the current sort. Of course the current crisis is not yet over, and the principal lesson to be drawn from this paper concerns governments rather more than central banks. What central banks have done is to buy time to allow governments to follow the policies ${ }^{129}$ that are more likely to lead to a resumption of "strong, sustainable and balanced" global growth. If governments do not use this time wisely, then the ongoing economic and financial crisis can only worsen as the unintended consequences of current monetary policies increasingly materialize.

\section{BIBLIOGRAPHY}

Adrian T and Shin HS.(2008a) “ Liquidity and Financial Cycles” - BIS Working Paper 256, Basel, July

Adrian T and Shin H.S(2008b) "Financial Intermediaries, Financial Stability and Monetary Policy" Federal Reserve Bank of New York Staff Reports, no. 346, September

Alloway T(2011a) "Towards the Limits of covered bond funding" -ft.com/alphaville, 16 March

Alloway T (2011b) "Bank Collateral drying up in rush for security " - Financial Times, 19 October

${ }^{129}$ For a fuller description of recommended policies, see White (2012) 
Altunbar Y, Eambacortal L and Marquez-Ibanez D (2010) "Does moneraty policy affect bank risk-taking BIS Working Paper 298, Basel, February

Antolin P, Schich S and Yermo J (2011) "The Economic impact of Protracted Low Interest Rates on Pension Funds and Insurance Companies" - OECD Journal: Financial Markets Trends - Vol 2011 - Issue 1, Paris

Bailey M J. (1992) "National Income and the Price Level” Mc Graw Hill Book Company, New York

Ball L (2012) “Ben Bernanke and the Zero Bound” John Hopkins University, Mimeo, February

Bank for International Settlements (2008) - Speech of the General Manager on the occasion of the Annual General Meeting, Basel June

Bank for International Settlements (2012) “Annual Report” - Basel, June

Beckworth D (2008) "Aggregate Supply Driven Deflation and Its Implications for Macroeconomic Stability" - Cato Journal, Vol 28, No3, Autumn

Beinhocker ED. (2006) "The Origin of Wealth" - Harvard Business School Press, Boston

Bernanke, Ben S (2000) “Japan's Slump: A Case of Self-Induced Paralysis? “ paper presented at American Economic Association meetings, January 2000; also, in Adam Posen and Ryoichi Mikitani, Japan's Financial Crisis and Its Parallels to US Experience, Institute for International Economics, September

Bernanke Ben S (2002) "Remarks at the Conference to Honor Milton Friedman" University of Chicago, Chicago, November

Bernanke, Ben S (2003) "Some thoughts on Monetary Policy in Japan" - www.frb.gov , 31 May

Bernanke, Ben S (2010) "What the Fed did and Why" - Washington Post, Washington, 4 November

Bernholz P (2006) "Monetary Regimes and Inflation: History, Economic and Political Relationships", Edward Elgar Publishing

Blanchard O, Dell'Ariccia G and Mauro P.V (2010) "Rethinking Macroeconomic Policy " - IMF Staff Position Note SPN/10/03, Washington, 12 February

Blustein P (2012) "How Global Watchdogs Missed a World of Trouble" - Centre for International Governance Innovation, Papers no 5, Waterloo, Ontario, July

Borio C.E.V and White W.R(2003) "Whither Monetary and Financial Stability : the Implications of Evolving Policy Regimes?" - Presentation at the Symposium "Monetary Policy and Uncertainty: Adapting to a changing Economy" Sponsored by the Federal Reserve Bank of Kansas City, Jackson Hole, Wyoming, August 
Borio C and Disyalat P (2004) "Unconventional Monetary Policies: an appraisal" - BIS Working Paper 292, Basel, November

Borio C and Zhu H (2008) "Capital Regulations, Risk-taking and Monetary Policy, a missing link in the transmission mechanism" - BIS Working Paper 268 - Basel, December

Borio C and Disyalat (2011) "Global Inbalances and the financial Crisis : link or no link ?" - BIS Working Paper 346, Basel, May

Buchanan M (2002) “Ubiquity: Why Catastrophes Happen" - Three Rivers Press, New York, November

Cecchetti S, Mohanty M and Zampotti F (2010) "The Future of Public Debt: Prospects and Implications" BIS Working Paper 300, Basel, March

Cecchetti S and Kharzoubi E (2012) "Reassessing the impact of Finance on Growth" - BIS Working Paper 381, Basel, July

Clement P (2010) “The Term Macroprudential: Origins and Evolution” - BIS Quarterly Review, March

Dickson E (2001) "The Implications of lower interest rates for insurers: a comment" - Geneva Papers on Risk and Insurance, Vol 25, No 1 January

Disyatat P (2010) “The Bank Lending Channel revisited" - BIS Working Paper 297, Basel, February

Dugger R (2011) “GE's Jeff Immelt understands FAC Discounting . Do you?” - Hanover Comment, 6 April

The Economist (2008) "The Biggest boom in history" - 7 june

European Union Chamber of Commerce (2009) "Overcapacity in China: Causes, Impacts and Recommendations"

Fahr S, Motto R, Rostagne M, Smets F and Tristani O (2010) "Lessons for Monetary Policy: Strategies from the Recent Past"- "Approaches to Monetary Policy Revisited - Lesson from the Crisis" - Sixth ECB Central Banking Confrerence, 18-19 November, Frankfurt

Financial Stability Board (2012) "Securities Lending and Repo: Market Overview and Financial Stability Issues" - Basel, April

Fisher R W and Rosenblum H (2012) "How big banks threaten the economy" Wall St Journal, 4 April

Fisher R W (2012) "The limits of the powers of central banks" Remarks at St Andrews University, St Andrews Scotland, 5 June

Flynbjerg B (2009) "Survival of the unfittest: why the worst insfrastructure gets built and what we can do about it" - Oxford Review of Economic Policy Vol.25, Number 3, pp 344-367

French D, de Haan R, Luck R and Mosbo J (2011) "The Impact of prolonged low interest rates on the Insurance Industry" - Ernst and Young, New York, October 
Galati G and Melick W (2004) "The evolving inflation process: an overview" - BIS Working Paper 196, Basel, February

Galati G, Heemeijer P and Moessner R (2011) "How do inflation expectations form : New insights from a high frequency survey" - BIS Working Paper 349, Basel, July

Galbraith J.K (1993) “A short History of Financial Euphoria” Penguin Books, New York

Gambacorta L (2009) "Monetary Policy and the Risk-taking Channel" - BIS Quarterly Review, Basel, December.

Geanakoplos J (2003) "Liquidity, Default, and Crashes: Endogenous Contracts in General Equilibrium" In M. Dewatripont, L.P. Hansen, and S.J. Turnovsky, eds. Advances In Economics and Econometrics: Theory and Applications, vol.2 - 170-205. Econometric Society Monographs: Eight World Congress, Cambridge University Press

Geanakoplos J (2010) "Solving the Present Crisis and managing the leverage Cycle" - Federal Reserve Bank of New York, Policy Review, New York, August

Gross B (2012) "Zero-Based Money Threatens and Traps Economic Recovery" - Financial Times, 7 February

Haberler G (1939) “Prosperity and Depression" - League of Nations, Geneva

Haberler G (1984) “Reflections on Hayek's Business Cycle Theory” - Cato Journal, Vol.6, Autumn

Haddock M and Barnes G (2012) "Swaps : the Unintended Consequences" - EMEA Viewpoint, CB RE, Quarter 1

Haldane A.G(2012) "Tails of the Unexpected" - Presentation at the Conference The Credit Crisis Five Years on: Unpacking the Crisis - University of Edinburgh Business School, 8-9 June

Hanoun H (2012) "Monetary Policy in the Crisis: Testing the Limits of Monetary Policy" - Speech delivered at the $47^{\text {th }}$ SEACEN Governor's Conference, Seoul, Korea, 13-14 February

Hoffman A (2012) "Zero Interest Rate Policy and Unintended Consequences in Emerging Markets" Mimeo, University of Leipzig, Institute for Economic policy, Leipzig 10 May

Hughes J (2011) “Concerns grow over collateral swap deals" - Financial Times, July

Independent Evaluation Office (2011) "IMF Performance in the Run-up of the Financial and Economic Crisis" - International Monetary Fund, Washington

Issing O (2012) "Central Banks - Paradise Lost" Centre for Financial Studies Working Paper 2012/06, Frankfurt, June

Johnson R (2010) “Credible Resolution: What it takes to end: Too Big to Fail” - Roosevelt Institute 
Johnson S (2009) "The Quiet Coup -Atlantic Magazine, May

Johnson S (2010) “Bond yield warning for UM Companies" Financial Times, 4 October

Jorda O, Schularick M and Taylor A.M (2012) "When credit bites back: leverage, business cycles and crises" - Paper prepared for a conference on "Debit and Credit Growth and Crises" hosted by the World Bank and the Bank of Spain, Madrid 18-19 June

Kaminska I (2012) "The terminal disease affecting banking" - Ft.com/alphaville- 18 July

Keynes J M.(1936) "The General Theory of Employment, Interest and Money" - Cambridge University Press, Cambridge

Kindelberger C.P and Aliber R.Z (2005) “Manias, Panics and Crashes” (Fifth Edition) Palgrave Macmillan, New York

Koo, R.C (2003) “Balance Sheet Recession" - John Wiley and Sons, Singapore

KPMG Global (2012) “Automotive Executive Survey”

Kregel J (2011) "Was Keynes's Monetary Policy, à Outrance in the Treatise, a Forerunner of ZIRP and QE? Did He Change His Mind in the General Theory? Policy Note 2011/4, Levy Economics Institute of Bard College

Laidler D (1999) “Fabricating the Keynesian Revolution" Cambridge University Press, Cambridge, UK

Lardy N.R (2012) "Sustaining China's Economic Growth after the Global Financial Crisis" - Peterson Institute, Washington, January

Leijonhufvud A (1968) "On Keynesian Economics and the Economics of Keynes" -Oxford University Press, London

Leijonhufvud A (2009) "Out of the Corridor: Keynes and the Crisis" - Cambridge Journal of Economics 33, PP. 741-757

Leijonhufvud A (2012) "The Unstable Web of Contracts" - Presentation at the INET Conference, Berlin, March

Lowe P. (2012) "Bank Regulation and the Future of Banking" - Remarks to the Australian Conference of Economists, Melbourne, 11 July

Maddaloni A and Peydro J-L (2010) "Bank Risk-Taking, securitisation, supervision and low interest rates: Evidence from the Euro Area and the US lending standards" - ECB Working Paper Series no 1248, October

Masters B, Jenkins P and Johnson M (2011) "Fears over Lenders Capital Tinkering" - Financial Times, 14 November 
McGregor R "The Party : The Secret World of China's Communist Rulers" - Harper Collins Books, New York

McGuire P and Goetz von P(2009) "The US dollar shortage in Global Banking" - BIS Quarterly Review , Basel, March

McKinsey Global Institute (2010) "Debt and Deleveraging: The Global Credit Bubble and its Economic Consequences" - New York, January

Merton R (2006) “ Observations on innovation in Pension Funds Management in the Impending future" - Presentation at the 2005 NCREIF Conference

Meyer G (2012) "Zero Interest rates will force brokers to hunt for new revenues" - Financial Times, 22 July

Mian A and Sufi A (2011) "What Explains High Unemployment ? The Agregate Demand Channel" NBER Working Paper 17830, February

Minsky H (1992) "The Financial Instability Hypothesis" - Jerome Levy Institute, Working Paper 74, May

Muellbauer J (2007) "Housing, Credit, and Consumer Expenditure" Presentation at the Symposium "Housing, Housing Finance and Monetary Policy" sponsored by the Federal Reserve Bank of Kansas City, Jackson Hole, Wyoming, August

Obstfeld M (2010) "Expanding Gross Asset Positions and the International Monetary System" Presentation at the Symposium "Macroeconomic Challenge: The Decade Ahead"

Sponsored by the Federal Reserve Bank of Kansas City, Jackson Hole, Wyoming, August

OECD (2011) “Divided We Stand" - Paris

Ostry J, Ghosh AR, Habermeier K, Chamon M, Qureshi MS and Reinhart DBS (2010) "Capital Inflows: The role of controls" - IMF, Staff Position Note, SPN 10/04

Peek J and Rosengren E.S (2003) "Perverse Incentives and the Misallocation of Credit in Japan" - NBER Working Paper no 9643.

Perotti E (2012) “The roots of shadow banking - VOX 21 June

Posen A S. (2011) “Central Bankers: Do something” - International Herald Tribune, 21 November

Pozsar Z, Adrian T, Askeraft A and Baesky H (2010) "Shadow Banking" Federal Reserve Bank of New York, Staff Report 458, New York, July

Powell, J (2003) “FDR's Follies, How Roosevelt and His New Deal Prolonged the Great Depression” ,New York: Random House

Rajan R.G (2005) "Has Financial Development Made the World Riskier?" - Presentation at the Symposium "The Greenspan Era: Lessons for the Future", sponsored by the Federal Reserve Bank of Kansas City, Jackson Hole, Wyoming, August 
Rajan R.G (2010) "Fault Lines: How Hidden Fault Lines Still Threaten the World Economy" - Princeton University Press, Princeton

Ramaswamy S (2011) " Market Structure and Systemic risks of Exchange - traded funds" - BIS Workshop Paper 343, Basel, April

Ramaswamy S (2012) "The Sustainability of Pension Schemes" - BIS Working Paper 368, Basel, January

Reinhart C. M and Reinhart V (2010) "After the Fall" - Presentation at the Symposium "Macroeconomic Challenges: The Decade Ahead" sponsored by the Federal Reserve Bank of Kansas City, Jackson Hole, Wyoming, August

Reinhart C.M and Rogoff K.S (2009) "This Time is Different: Eight Centuries of Financial Folly" Princeton University Press, Princeton, NJ

Rogoff K.S (2011) "Global and Monetary Policy Overview and Recent Issues" - Presentation to a Symposium on "Which regulation for Global Imbalances?" sponsored by the Bank of France, Paris, March

Shin HS (2011) "Global Banking Glut and Loan Risk Premium" Mundell-Fleming Lecture, Princeton University, Princeton

Shirakawa M (2012a) "Develeraging and Growth: Is the Developed World Following Japan's Long and Winding Road?" - Lecture at the London School of Economics, London, 10 January

Shirakawa M (2012b) “The Bank of Japan's Efforts toward Overcoming Deflation” - Speech at the Japan National Press Club, Tokyo, 17 February

Singh M and Aitken J (2010) "The Sizable Role of Rehypothecation in the Shadow Banking System" - IMF Working Paper 10/172 - Washington, July

Singh M (2011) "Velocity of Pledged Collateral: Analysis and Implications" - IMF Working Paper 11/256 Washington, November

Slovik P (2011) "Systemically Important Banks and Capital Regulation Changes " - OECD Economic Working Papers No 916, Paris

Smiley, G (2002) “ Rethinking the Great Depression”, Chicago: Ivan R.Dee, 2002

Soros G. (2010) "The Soros Lectures at the Central European University" - Public Affairs, New York

Standards and Poors (2011) "Interest Rate Risk in 2012 : With low rates persisting, Insurance Companies try to muddle through" - November

Summers L and Delong B (2012) "Fiscal policy in a depressed economy" BPEA Spring

Svenson L (2003) "Escaping from the liquidity trap and deflation: the foolproof way and others" Journal of Economic Perspectives Vol 17 No 4 
Tett G (2012) "Size can be deadly in a low rate world" Financial Times 17 May

Turner P.(2011) "Is the long-term interest rate a policy victim, a policy variable or a policy lodestar" - BIS Working Paper 367, Basel, December

Waldrop M.M.(1992) “Complexity" - Lemon and Schuster Paperbacks - New York

Wedel JR.(2009) “Shadow Elite” - Basic Books, New York

White W.R (2004) "Are changes in Financial Structure Extending Safety Nets?" - BIS Working Paper 250, Basel

White W.R(2006a) “Is Price Stability Enough?” - BIS Working Paper 205, April

White W.R(2006b) "Measured Wealth, Real Wealth and the Illusion of Saving" Presentation to a Conference Organized by the Irving Fisher Committee, Basel, August

White W.R(2008) "Globalization and the Determinants of Domestic Inflation" -BIS Working Paper 250, Basel, March

White W.R(2010) "The Mayekawa Lecture: Some Alternative Perspectives on Macroeconomic Theory and Some Policy Implications" - Monetary and Economic Studies, Institute for Monetary and Economic Studies, Bank of Japan, Vol.28, November

White W.R(2011) "Why All Central Banks Are Not the Same" in Gokarn S (ed.) "Challenges to Central Banking in the Context of Financial Crises" - Reserve Bank of India and Academic Foundation, New Dehli, February

White W R (2012a) "Macroprudential Regulatory Policies: The New Road to Financial Stability" in Claessens S, Evanoff D, Kaufman G, and Kodres I (eds) "Macroprudential Regulatory Policies: The New Road to Financial Stability" - World Scientific Press, Singapore, pp 357-370

White W.R(2012b) "Credit Crises and the Shortcomings of Traditional Policy Responses" - OECD, Economics Department - Working Paper No 971, Paris

Yamaguchi Y (1999) "Asset Prices and Monetary Policy: Japan's Experience" - Panel Presentation at the Symposium "New Challenges for Monetary Policy" organized By the Federal Reserve Bank of Kansas City, Jackson Hole, Wyoming, February 